\title{
New Oral Anticoagulants for the Treatment of Venous Thromboembolism: Understanding Differences and Similarities
}

\author{
Paul P. Dobesh · John Fanikos
}

Published online: 10 October 2014

(c) The Author(s) 2014. This article is published with open access at Springerlink.com

\begin{abstract}
Venous thromboembolism (VTE) is a major cause of morbidity, mortality, and healthcare expenditure. In the United States, approximately $0.1 \%$ of the population experiences an initial VTE event each year. Anticoagulation therapy is the cornerstone of acute VTE treatment and for prevention of recurrent VTE events. Conventional anticoagulants, including heparin, lowmolecular-weight heparins, fondaparinux, and vitamin $\mathrm{K}$ antagonists are widely used but have limitations. Newer oral anticoagulant agents, including direct thrombin inhibitors (e.g., dabigatran etexilate) and direct factor Xa inhibitors (e.g., rivaroxaban, apixaban, and edoxaban) have been developed to attempt to overcome some of the limitations of conventional anticoagulant therapy. These new oral agents have been evaluated for safety and efficacy in large, randomized clinical trials in the treatment and secondary prevention of VTE with results that are comparable to conventional therapy. Dabigatran, rivaroxaban, apixaban, and edoxaban are important new treatment options for patients with VTE. In this review, we compare these new agents and their associated clinical trials in VTE treatment.
\end{abstract}

P. P. Dobesh ( $\square)$

University of Nebraska Medical Center, 986045 Nebraska

Medical Center, Omaha, NE 68198-6045, USA

e-mail: pdobesh@unmc.edu

J. Fanikos

Department of Pharmacy Services, Brigham and Women's

Hospital, 75 Francis Street, Boston, MA 02115, USA

\section{Introduction}

Venous thromboembolism (VTE), encompassing deep vein thrombosis (DVT) and pulmonary embolism (PE), is a significant healthcare concern resulting in substantial morbidity, mortality, and resource expenditure. A first VTE event occurs in approximately $0.1 \%$ of people in the United States (US) each year [1]. In 2006, the incidences of patients admitted to hospital for DVT and PE were 52 per 100,000 and 49 per 100,000 persons, respectively [2], which is consistent with a community VTE incidence reported at 104 events per 100,000 population [3]. Patients with a first episode of VTE are at an increased risk of recurrence $[1,4,5]$. In a study of 1,626 patients, the cumulative incidence of recurrent VTE was 11.0, 19.6, 29.1 , and $39.9 \%$ after $1,3,5$, and 10 years, respectively [6], and in a systematic review, the rate of recurrence of VTE at 24 months was $3.3 \%$ per patient-year for all patients with a transient risk factor and $7.4 \%$ per patientyear after unprovoked VTE [7]. Risk factors associated with the development of recurrent VTE include the presence of reversible provoking risk factors (e.g., recent surgery, use of estrogen-based oral contraception), previous unprovoked VTE, and the presence of active cancer [7, 8]. In almost $25 \%$ of patients stricken with PE, the initial clinical manifestation is sudden death, with mortality exceeding $15 \%$ in the first 3 months after diagnosis [9, 10]. A study evaluating short- and long-term mortality after 67,354 definite and 35,123 probable cases of VTE found 30-day and 1-year case fatality rates of 10.6 and $23.0 \%$, respectively [11].

Initial and recurrent VTE episodes are associated with high healthcare costs. A study assessing administrative claims from 30 managed care organizations found the average total annualized healthcare cost of a patient with a 
primary diagnosis of DVT was US\$10,804 and US\$16,644 for a patient with PE [12]. Most of the costs can be attributed to hospitalization, facility and professional costs, and outpatient procedure costs. Recurrent episodes of VTE were also associated with increased costs. Total hospitalization costs for patients readmitted with DVT were US\$2,057 more than the initial hospitalization [12]. This increase was primarily due to a longer length of hospital stay for the recurrent episode. Another medical center study reported treating an average of 160 hospitalized patients with PE per year and incurring annual treatment expenses ranging from approximately US\$900,000 to US\$1.9 million [13].

Anticoagulant therapy is necessary to prevent early and late episodes of recurrent VTE [4]. Currently available therapies include conventional anticoagulants, such as unfractionated heparin (UFH), low-molecular-weight heparins (LMWHs), fondaparinux, and vitamin $\mathrm{K}$ antagonists (VKAs). Each conventional anticoagulant is associated with intrinsic limitations, such as unpredictable pharmacokinetics and pharmacodynamics, monitoring requirements, parenteral administration, drug-food or drug-drug interactions, and potentially severe adverse events. New oral anticoagulants (NOACs) have advantages that make them beneficial treatment options for patients with acute VTE as well as for prevention of recurrent events. Here, we examine the data on the direct thrombin inhibitor dabigatran etexilate, and direct factor $\mathrm{Xa}$ inhibitors rivaroxaban, apixaban, and edoxaban to gain a better understanding of how each agent fits into the landscape of therapeutic options for VTE management. Currently, rivaroxaban, apixaban, and dabigatran are approved by the US Food and Drug Administration (FDA) for the treatment of acute VTE and prevention of recurrence. Edoxaban has been studied in phase III studies and is currently under evaluation by the FDA.

\section{New Oral Anticoagulants}

Dabigatran has been evaluated for the acute treatment of VTE in the RE-COVER (Efficacy and Safety of Dabigatran Compared to Warfarin for 6 Month Treatment of Acute Symptomatic Venous Thromboembolism) I and II trials $[14,15]$. To increase the robustness of the data supporting the use of dabigatran in acute VTE treatment, the RECOVER II trial was conducted using the same trial design and outcome measures as the RE-COVER I trial [15]. The efficacy and safety of rivaroxaban in the acute treatment of VTE was assessed in two separate trials, EINSTEIN-DVT and EINSTEIN-PE (Oral Direct Factor Xa Inhibitor Rivaroxaban in Patients With Acute Symptomatic Deep-Vein Thrombosis or Pulmonary Embolism) $[16,17]$. Aside from the index event in the patients enrolled in each trial, the study designs were identical. Apixaban has been evaluated in the acute treatment of VTE in the AMPLIFY (Apixaban for the Initial Management of Pulmonary Embolism and Deep-Vein Thrombosis as First-Line Therapy) trial [18]. The efficacy and safety of edoxaban for the acute treatment of VTE was evaluated in the Hokusai-VTE trial [19]. An overview of these trials is presented in Table 1.

\section{Study Design}

\subsection{Treatment Protocols}

The RE-COVER I and II, AMPLIFY, and Hokusai-VTE trials were all conducted in a double-blinded fashion, with international normalized ratio (INR) testing incorporated through an encrypted point-of-care device providing accurate and sham results [14, 15, 18, 19]. In contrast, the EINSTEIN trials had an open-label design (Table 1) [16, 17]. All of the studies had a comparator arm reflecting standard of care-parenteral anticoagulant administered along with a VKA. However, the approaches to parenteral anticoagulant use in the investigational treatment arms differed among the trials. The RE-COVER and HokusaiVTE trials both incorporated initial treatment with a heparin agent for at least 5 days [14, 15, 19]. The second approach, employed in the EINSTEIN and AMPLIFY trials, was NOAC monotherapy. The rationale for initial parenteral therapy originated from a prior trial using the investigational direct thrombin inhibitor ximelagatran. Here, the recurrent VTE rate was elevated during the early treatment period in patients receiving a fixed-dose oral anticoagulant compared with standard of care [20]. To address this, the EINSTEIN and AMPLIFY studies initiated treatment with a higher dose of their respective agents, without initial parenteral anticoagulation, before reducing to a lower maintenance dose [16-18].

An additional difference in dosing strategies, unique to the edoxaban trial, was the incorporation of predetermined dose reductions in response to the presence of certain characteristics that could lead to increased drug exposure [19]. In the Hokusai-VTE trial, patients with a creatinine clearance $(\mathrm{CrCl}) \geq 30$ to $\leq 50 \mathrm{~mL} / \mathrm{min}$, a body weight of $\leq 60 \mathrm{~kg}$, or those receiving concomitant treatment with a potent $\mathrm{P}$-glycoprotein $(\mathrm{P}$-gp) inhibitor were given a dose of edoxaban of $30 \mathrm{mg}$ once daily instead of $60 \mathrm{mg}$ once daily [19, 21]. After randomization, if the patient's $\mathrm{CrCl}$ changed to $\geq 30$ to $\leq 50 \mathrm{~mL} / \mathrm{min}$ (confirmed by repeat measurement at least 1 week apart) and the $\mathrm{CrCl}$ change was $>20 \%$ from baseline, the edoxaban dose was reduced permanently [19]. Similarly, if the patient's body weight dropped to $\leq 60 \mathrm{~kg}$ (confirmed by repeat measurement at least 1 week 
Table 1 General overview of clinical trial design

\begin{tabular}{|c|c|c|c|c|c|c|}
\hline Criteria & $\begin{array}{l}\text { RE-COVER I } \\
{[14]}\end{array}$ & $\begin{array}{l}\text { RE-COVER II } \\
{[15]}\end{array}$ & $\begin{array}{l}\text { EINSTEIN-DVT } \\
{[16]}\end{array}$ & EINSTEIN-PE [17] & AMPLIFY [18] & Hokusai-VTE [19] \\
\hline Study design & \multicolumn{2}{|c|}{$\begin{array}{l}\text { Randomized, double-blind, non- } \\
\text { inferiority, parallel group }\end{array}$} & \multicolumn{2}{|c|}{$\begin{array}{l}\text { Randomized, open-label, event-driven, } \\
\text { non-inferiority, parallel group }\end{array}$} & $\begin{array}{l}\text { Randomized, double- } \\
\text { blind, parallel group }\end{array}$ & $\begin{array}{l}\text { Randomized, double- } \\
\text { blind, non-inferiority, } \\
\text { parallel group }\end{array}$ \\
\hline Intervention & $\begin{array}{l}\text { Dabigatran } \\
\text { etexilate } \\
150 \mathrm{mg} \text { bid } \\
(n=1,274)\end{array}$ & $\begin{array}{l}\text { Dabigatran } \\
\text { etexilate } \\
150 \mathrm{mg} \text { bid } \\
(n=1,279)\end{array}$ & $\begin{array}{l}\text { Rivaroxaban } \\
15 \mathrm{mg} \text { bid for } \\
3 \text { weeks, } \\
\text { followed by } \\
20 \mathrm{mg} \text { od } \\
n=1,731\end{array}$ & $\begin{array}{l}\text { Rivaroxaban } 15 \mathrm{mg} \\
\text { bid for } 3 \text { weeks, } \\
\text { followed by } 20 \mathrm{mg} \\
\text { od } n=2,419\end{array}$ & $\begin{array}{l}\text { Apixaban } 10 \mathrm{mg} \text { bid for } \\
7 \text { days, followed by } \\
5 \mathrm{mg} \text { bid } n=2,676\end{array}$ & $\begin{array}{l}\text { Edoxaban } 60 \mathrm{mg} \text { od or } \\
\text { edoxaban } 30 \mathrm{mg} \text { od in } \\
\text { patients with a CrCl of } \\
30-50 \mathrm{~mL} / \mathrm{min} \text {, body } \\
\text { weight } \leq 60 \mathrm{~kg} \text { or } \\
\text { receiving strong P-gp } \\
\text { inhibitors } n=4,118\end{array}$ \\
\hline Comparator & $\begin{array}{l}\text { Warfarin } \\
\text { dose- } \\
\text { adjusted to } \\
\text { INR } \\
2.0-3.0 \\
n=1,265\end{array}$ & $\begin{array}{l}\text { Warfarin dose- } \\
\text { adjusted to } \\
\text { INR } 2.0-3.0 \\
n=1,289\end{array}$ & $\begin{array}{l}\text { Enoxaparin } 1 \mathrm{mg} / \\
\text { kg bid } \\
\text { ( } \geq 5 \text { days)/VKA } \\
\text { (warfarin or } \\
\text { acenocoumarol) } \\
\text { dose-adjusted to } \\
\text { INR } 2.0-3.0 \\
n=1,718\end{array}$ & $\begin{array}{l}\text { Enoxaparin } 1 \mathrm{mg} / \mathrm{kg} \\
\text { bid ( } \geq 5 \text { days)/ } \\
\text { VKA (warfarin or } \\
\text { acenocoumarol) } \\
\text { dose-adjusted to } \\
\text { INR } 2.0-3.0 \\
n=2,413\end{array}$ & $\begin{array}{l}\text { Enoxaparin } 1 \mathrm{mg} / \mathrm{kg} \text { bid } \\
\text { ( } \geq 5 \text { days)/warfarin } \\
\text { dose-adjusted to INR } \\
2.0-3.0 \\
n=2,689\end{array}$ & $\begin{array}{l}\text { Warfarin dose-adjusted } \\
\text { to INR } 2.0-3.0 \\
n=4,122\end{array}$ \\
\hline $\begin{array}{l}\text { Parenteral } \\
\text { anticoagulation }\end{array}$ & \multicolumn{2}{|c|}{ Mandatory, at least 5 days } & \multicolumn{2}{|c|}{ Optional, maximum $48 \mathrm{~h}$} & Optional, maximum $36 \mathrm{~h}$ & $\begin{array}{l}\text { Mandatory, at least } \\
5 \text { days }\end{array}$ \\
\hline Inclusion criteria & $\begin{array}{l}\text { Symptomatic } \\
\text { uni- or } \\
\text { bilateral } \\
\text { proximal } \\
\text { DVT or PE } \\
\text { (with or } \\
\text { without } \\
\text { DVT) }\end{array}$ & $\begin{array}{l}\text { Symptomatic } \\
\text { proximal } \\
\text { DVT or PE } \\
\text { (with or } \\
\text { without } \\
\text { DVT) }\end{array}$ & $\begin{array}{l}\text { Symptomatic } \\
\text { proximal DVT } \\
\text { without } \\
\text { symptomatic PE }\end{array}$ & $\begin{array}{l}\text { Symptomatic PE } \\
\text { with or without } \\
\text { symptomatic DVT }\end{array}$ & $\begin{array}{l}\text { Symptomatic proximal } \\
\text { DVT or PE (with or } \\
\text { without DVT) }\end{array}$ & $\begin{array}{l}\text { Symptomatic proximal } \\
\text { DVT or PE (with or } \\
\text { without DVT) }\end{array}$ \\
\hline $\begin{array}{c}\text { Anatomical } \\
\text { definition }\end{array}$ & \multicolumn{2}{|c|}{$\begin{array}{l}\text { Proximal defined as trifurcation } \\
\text { area, popliteal, superficial } \\
\text { femoral, deep femoral, } \\
\text { common femoral, and iliac } \\
\text { veins }\end{array}$} & $\begin{array}{l}\text { Proximal defined } \\
\text { as the iliac vein, } \\
\text { common femoral } \\
\text { vein, superficial } \\
\text { femoral vein, } \\
\text { and popliteal } \\
\text { vein }\end{array}$ & $\begin{array}{l}\text { PE defined as an } \\
\text { intraluminal filling } \\
\text { defect in } \\
\text { segmental or more } \\
\text { proximal branches }\end{array}$ & $\begin{array}{l}\text { Proximal defined as } \\
\text { involving at least the } \\
\text { popliteal vein or a } \\
\text { more proximal vein }\end{array}$ & $\begin{array}{l}\text { Proximal defined as } \\
\text { involving the popliteal, } \\
\text { femoral, or iliac veins }\end{array}$ \\
\hline $\begin{array}{l}\text { Objective testing } \\
\text { for suspected } \\
\text { PE }\end{array}$ & \multicolumn{2}{|c|}{$\begin{array}{l}\text { Confirmed by ventilation- } \\
\text { perfusion lung scan, } \\
\text { pulmonary angiography, or } \\
\text { spiral CT } \\
\text { Additional baseline exams } \\
\text { (bilateral CUS) were } \\
\text { performed no later than } 72 \mathrm{~h} \\
\text { after randomization to } \\
\text { facilitate adjudication of } \\
\text { suspected recurrence }\end{array}$} & \multicolumn{4}{|c|}{$\begin{array}{l}\text { Intraluminal filling defect in segmental or more proximal branches on spiral CT, or a (new) } \\
\text { intraluminal filling defect or extension of an existing defect or a new sudden cutoff of vessels } \\
\geq 2.5 \mathrm{~mm} \text { in diameter on pulmonary angiogram, or a (new) perfusion defect of at least } 75 \% \text { of a } \\
\text { segment with a local normal ventilation result (high probability) on ventilation/perfusion lung } \\
\text { scintigraphy }\end{array}$} \\
\hline $\begin{array}{l}\text { Objective testing } \\
\text { for suspected } \\
\text { DVT }\end{array}$ & \multicolumn{2}{|c|}{$\begin{array}{l}\text { Confirmed by venous CUS or } \\
\text { venography } \\
\text { Additional baseline exams } \\
\text { (CUS in symptom-free leg, } \\
\text { bilateral CUS when the initial } \\
\text { DVT diagnosis was made by } \\
\text { venography, perfusion lung } \\
\text { scan or lung spiral CT) were } \\
\text { performed no later than } 72 \mathrm{~h} \\
\text { after randomization to } \\
\text { facilitate adjudication of } \\
\text { suspected recurrence }\end{array}$} & $\begin{array}{l}\text { Confirmed by an } \\
\text { abnormal CUS } \\
\text { or an } \\
\text { intraluminal } \\
\text { filling defect on } \\
\text { venography }\end{array}$ & $\begin{array}{l}\text { Confirmed by } \\
\text { abnormal CUS, } \\
\text { including grey- } \\
\text { scale or color- } \\
\text { coded Doppler, or } \\
\text { an intraluminal } \\
\text { filling defect of } \\
\text { venography }\end{array}$ & $\begin{array}{l}\text { Confirmed by a } \\
\text { noncompressible } \\
\text { venous segment on } \\
\text { ultrasonography, or an } \\
\text { intraluminal filling } \\
\text { defect on venography, } \\
\text { or an intraluminal } \\
\text { filling defect on spiral } \\
\text { CT of the leg }\end{array}$ & $\begin{array}{l}\text { Objective testing for } \\
\text { suspected DVT (no } \\
\text { prior testing) or an } \\
\text { extension of an } \\
\text { intraluminal filling } \\
\text { defect on spiral CT/ } \\
\text { contrast of the leg }\end{array}$ \\
\hline $\begin{array}{l}\text { Primary efficacy } \\
\text { endpoint }\end{array}$ & \multicolumn{2}{|c|}{$\begin{array}{l}\text { Recurrent symptomatic VTE or } \\
\text { death related to VTE }\end{array}$} & $\begin{array}{l}\text { Recurrent } \\
\text { symptomatic } \\
\text { VTE }\end{array}$ & $\begin{array}{l}\text { Recurrent } \\
\text { symptomatic VTE }\end{array}$ & $\begin{array}{l}\text { Recurrent symptomatic } \\
\text { VTE or death related to } \\
\text { VTE }\end{array}$ & $\begin{array}{l}\text { Recurrent symptomatic } \\
\text { VTE }\end{array}$ \\
\hline
\end{tabular}


Table 1 continued

\begin{tabular}{|c|c|c|c|c|c|c|}
\hline Criteria & $\begin{array}{l}\text { RE-COVER I } \\
{[14]}\end{array}$ & $\begin{array}{l}\text { RE-COVER II } \\
{[15]}\end{array}$ & $\begin{array}{l}\text { EINSTEIN-DVT } \\
{[16]}\end{array}$ & EINSTEIN-PE [17] & AMPLIFY [18] & Hokusai-VTE [19] \\
\hline $\begin{array}{l}\text { Primary safety } \\
\text { endpoint }\end{array}$ & Major bleeding & & $\begin{array}{l}\text { Major or CRNM } \\
\text { bleeding }\end{array}$ & $\begin{array}{l}\text { Major or CRNM } \\
\text { bleeding }\end{array}$ & Major bleeding & $\begin{array}{l}\text { Major or CRNM } \\
\text { bleeding }\end{array}$ \\
\hline $\begin{array}{r}\text { Treatment } \\
\text { duration }\end{array}$ & 6 months & & 3,6 , or 12 month & pre-specified) & 6 months & 3-12 months (flexible) \\
\hline
\end{tabular}

bid twice daily, $\mathrm{CrCl}$ creatinine clearance, $C R N M$ clinically relevant non-major, $C U S$ compression ultrasound, $D V T$ deep vein thrombosis, INR international normalized ratio, $o d$ once daily, $P E$ pulmonary embolism, VKA vitamin $\mathrm{K}$ antagonist, VTE venous thromboembolism

apart) and the change was $>10 \%$ of baseline, the edoxaban dose was reduced permanently. While verapamil, quinidine, and dronedarone were the only P-gp inhibitors allowed at the time of randomization, concomitant use of any protease inhibitor was prohibited. The P-gp inhibitors erythromycin, azithromycin, clarithromycin, ketoconazole, and itraconazole were prohibited at the time of randomization, but subsequent use was permitted after randomization. When verapamil, quinidine, dronedarone, erythromycin, azithromycin, clarithromycin, ketoconazole, or itraconazole were used concurrently, the edoxaban dose was reduced to $30 \mathrm{mg}$ daily. Conversely, the edoxaban dosing regimen was returned to $60 \mathrm{mg}$ daily when the patient was no longer taking the concomitant medication [19].

Another difference in study designs was treatment duration. Both the RE-COVER and AMPLIFY trials had treatment durations of 6 months $[14,15,18]$. In the EINSTEIN trials, patients could have received treatment for 3 , 6 , or 12 months based on the discretion of the investigator, but the desired duration of therapy had to be determined at the time of randomization. A 3-month duration was intended in patients with a transient risk factor (recent surgery, trauma, immobilization, estrogen use, puerperium). A 6- or 12-month duration was intended for patients with idiopathic VTE or permanent risk factors (active cancer, previous VTE, thrombophilia) [16, 17]. In the Hokusai-VTE trial, treatment duration was for a minimum of 3 months and up to a maximum of 12 months, as determined by the investigator. In the Hokusai-VTE trial, unlike the other clinical trials, efficacy outcomes were assessed over the entire study treatment period of 12 months regardless of the duration of treatment (3-12 months) [19]. Safety and net clinical benefit were assessed only during the on-treatment period.

\subsection{Inclusion and Exclusion}

Except for the EINSTEIN trials, each trial had similar inclusion criteria, requiring the presence of symptomatic proximal DVT with or without PE (Table 1). The EINSTEIN-DVT trial required symptomatic proximal DVT without PE, and the EINSTEIN-PE trial required the presence of symptomatic PE, with or without DVT [16, 17]. All trials required objective testing for diagnosis of initial and recurrent events (Table 1).

While venography is considered the standard diagnostic study against which all others are judged, the primary diagnostic method for DVT in the US is compression ultrasound (CUS). CUS has high sensitivity (>92\%), specificity $(>97 \%)$, and high interobserver agreement $(\kappa=1)$ for first-episode proximal DVT [22]. However, CUS-evident abnormalities continue to be present in approximately $80 \%$ of patients at 3 months and in $50 \%$ of patients after 1 year following a proximal DVT. Regardless of the ultrasound method used, proximal DVT is more accurately diagnosed than distal DVT [22]. Similarly, residual pulmonary thrombi can be detected on CT scan up to 11 months after the index PE [23]. Therefore, it becomes difficult to determine whether a suspected event in the same leg or pulmonary vein is new or residual thrombosis from the index event.

Each trial employed venography and CUS for DVT diagnosis. Only RE-COVER I and II mandated baseline exams and imaging of the symptom-free extremity to facilitate adjudication of recurrent events [14, 15]. This more stringent investigation could, in part, explain the numerically higher recurrent symptomatic DVT event rates when comparing RE-COVER I and II with EINSTEINDVT and AMPLIFY trials. The AMPLIFY trial included duplex ultrasonography (grey-scale or color-coded Doppler), a more comprehensive exam [18, 24]. In the HokusaiVTE trial, diagnostic testing also included spiral computed tomography (CT) of the lower extremities [19]. In the EINSTEIN, AMPLIFY, and Hokusai-VTE trials, recurrent events were diagnosed when thrombosis was detected in a new or previously normal segment [16-19]. Similarly, recurrent DVT was diagnosed by measuring changes in vein diameter over time, defined as an increase in thrombus diameter to $4 \mathrm{~mm}$ in a previously affected vein segment, as opposed a reduction or no change in size [25]. All trials utilized a blinded central adjudication committee for the evaluation of all suspected efficacy and safety outcome events. In the RE-COVER trials, autopsies were conducted 
Table 2 Comparison of clinical trial exclusion criteria

\begin{tabular}{|c|c|c|c|c|}
\hline Criteria & $\begin{array}{l}\text { RE-COVER I, II } \\
{[14,15]}\end{array}$ & $\begin{array}{ll}\text { EINSTEIN- } & \text { EINSTEIN- } \\
\text { DVT [16] } & \text { PE [17] }\end{array}$ & AMPLIFY [18] & Hokusai-VTE [19] \\
\hline Exclusion & Symptoms $>14$ days & \multicolumn{3}{|l|}{ Not defined } \\
\hline Prior intervention & $\begin{array}{l}\text { Thrombolytic therapy } \\
\text { within } 14 \text { days } \\
\text { IVC filter, or } \\
\text { anticipated use }\end{array}$ & \multicolumn{3}{|c|}{ Thrombolysis, thrombectomy, or insertion of IVC filter for current episode } \\
\hline $\begin{array}{l}\text { Parenteral } \\
\text { anticoagulation } \\
\text { prior to } \\
\text { randomization }\end{array}$ & $\begin{array}{l}\text { UFH, LMWH, } \\
\text { fondaparinux }>72 \mathrm{~h}\end{array}$ & $\begin{array}{l}\text { UFH, LMWH, } \\
\text { fondaparinux }>48 \mathrm{~h}\end{array}$ & $\begin{array}{l}\mathrm{UFH}>36 \mathrm{~h} \text {, daily LMWH, or } \\
\text { fondaparinux }>2 \text { doses, twice } \\
\text { daily LMWH }>3 \text { doses }\end{array}$ & $\begin{array}{l}\text { UFH, LMWH, fondaparinux } \\
>48 \mathrm{~h}\end{array}$ \\
\hline $\begin{array}{l}\text { Oral } \\
\text { anticoagulation }\end{array}$ & \multicolumn{4}{|c|}{ VKA for another indication } \\
\hline $\begin{array}{l}\text { Prior oral } \\
\text { anticoagulation }\end{array}$ & $>2$ doses & $>1$ dose & $>2$ doses & $>1$ dose \\
\hline Contraindications & $\begin{array}{l}\text { Contraindication to } \\
\text { heparins or } \\
\text { alternative therapies } \\
\text { for initial treatment } \\
\text { and warfarin }\end{array}$ & $\begin{array}{l}\text { Contraindication to } \\
\text { enoxaparin, warfarin, } \\
\text { and acenocoumal }\end{array}$ & \multicolumn{2}{|c|}{ Contraindication to UFH, LMWH, or any VKA } \\
\hline Renal function & $\begin{array}{l}\text { Estimated } \mathrm{CrCl} \\
\quad \leq 30 \mathrm{~mL} / \mathrm{min}\end{array}$ & $\mathrm{CrCl}<30 \mathrm{~mL} / \mathrm{min}$ & $\begin{array}{l}\mathrm{CrCl}<25 \mathrm{~mL} / \mathrm{min} \text {, serum creatinine } \\
>2.5 \mathrm{mg} / \mathrm{dL}\end{array}$ & Calculated $\mathrm{CrCl}<30 \mathrm{~mL} / \mathrm{min}$ \\
\hline $\begin{array}{l}\text { Uncontrolled } \\
\text { hypertension }\end{array}$ & N/A & $\begin{array}{l}\text { Systolic blood pressure } \\
>180 \mathrm{mmHg} \text { or } \\
\text { diastolic blood pressure } \\
>110 \mathrm{mmHg}\end{array}$ & $\begin{array}{l}\text { Systolic blood pressure } \\
>180 \mathrm{mmHg} \text { or diastolic blood } \\
\text { pressure }>100 \mathrm{mmHg}\end{array}$ & $\begin{array}{l}\text { Systolic blood pressure } \\
>170 \mathrm{mmHg} \text { or diastolic } \\
\text { blood pressure }>100 \mathrm{mmHg}\end{array}$ \\
\hline Hepatic function & $\begin{array}{l}\text { Hepatic disease (ALT } \\
\text { or AST } 2 \times \text { ULN, } \\
\text { RE-COVER I, } 3 \times \\
\text { ULN, RE-COVER } \\
\text { II) }\end{array}$ & $\begin{array}{l}\text { Hepatic disease, ALT or } \\
\text { AST } 3 \times \text { ULN }\end{array}$ & $\begin{array}{l}\text { Hepatic disease, ALT or AST } 2 \times \\
\text { ULN, total bilirubin } 1.5 \times \text { ULN }\end{array}$ & $\begin{array}{l}\text { Hepatic disease, ALT } \geq 2 \times \\
\text { ULN, total bilirubin } \geq 1.5 \times \\
\text { ULN }\end{array}$ \\
\hline Life expectancy & $<6$ months & \multirow[t]{2}{*}{$<3$ months } & $<6$ months & $<3$ months \\
\hline Cancer & Not defined & & $\begin{array}{l}\text { Subjects with cancer who will be } \\
\text { treated with LMWH for } \\
\geq 6 \text { months }\end{array}$ & $\begin{array}{l}\text { Active cancer where long-term } \\
\text { treatment with LMWH is } \\
\text { anticipated }\end{array}$ \\
\hline $\begin{array}{l}\text { Child-bearing } \\
\text { potential }\end{array}$ & $\begin{array}{r}\text { Pregnancy or risk of } \\
\text { becoming pregnant }\end{array}$ & $\begin{array}{l}\text { Pregnancy, child-bearing } \\
\text { potential without } \\
\text { contraception, breast } \\
\text { feeding }\end{array}$ & $\begin{array}{l}\text { Pregnancy, child-bearing potential } \\
\text { unable/willing to use } \\
\text { contraception, breast feeding }\end{array}$ & $\begin{array}{l}\text { Pregnancy, breast feeding, } \\
\text { child-bearing potential } \\
\text { without proper contraceptive } \\
\text { methods }\end{array}$ \\
\hline $\begin{array}{l}\text { Cardiovascular } \\
\text { disease }\end{array}$ & $\begin{array}{l}\text { Endocarditis, } \\
\text { myocardial } \\
\text { infarction within last } \\
3 \text { months }\end{array}$ & Endocarditis & & Not defined \\
\hline Bleeding risk & High bleeding risk & $\begin{array}{l}\text { Active bleeding or high } \\
\text { risk of bleeding }\end{array}$ & $\begin{array}{l}\text { Active bleeding or high risk of } \\
\text { bleeding }\end{array}$ & $\begin{array}{l}\text { Active bleeding or high } \\
\text { bleeding risk } \\
\text { contraindicating treatment } \\
\text { with UFH or LMWH }\end{array}$ \\
\hline $\begin{array}{l}\text { Laboratory } \\
\text { parameters }\end{array}$ & $\begin{array}{l}\text { Hemoglobin }<10 \mathrm{mg} / \\
\text { dL, platelet count } \\
<100,000 / \mathrm{mm}^{3}\end{array}$ & Not defined & $\begin{array}{l}\text { Hemoglobin }<9 \mathrm{mg} / \mathrm{dL}, \text { platelet } \\
\text { count }<100,000 / \mathrm{mm}^{3}\end{array}$ & Not defined \\
\hline $\begin{array}{l}\text { Trauma or major } \\
\text { surgery }\end{array}$ & Within last month & Not defined & Within last 2 months & Not defined \\
\hline $\begin{array}{l}\text { Intracranial, } \\
\text { intraocular } \\
\text { bleed }\end{array}$ & Any history & Not defined & Within last 6 months & Not defined \\
\hline GI bleed & Within last 3 months & Not defined & Within last 6 months & Not defined \\
\hline
\end{tabular}


Table 2 continued

\begin{tabular}{|c|c|c|c|c|}
\hline Criteria & $\begin{array}{l}\text { RE-COVER I, II } \\
{[14,15]}\end{array}$ & $\begin{array}{ll}\text { EINSTEIN- } & \text { EINSTEIN- } \\
\text { DVT [16] } & \text { PE [17] }\end{array}$ & AMPLIFY [18] & Hokusai-VTE [19] \\
\hline $\begin{array}{l}\text { Hemorrhagic } \\
\text { disorder }\end{array}$ & Any history & \multirow[t]{2}{*}{ Not defined } & Any history & Not defined \\
\hline $\begin{array}{l}\text { Concurrent } \\
\text { aspirin } \\
\text { excluded }\end{array}$ & $>100 \mathrm{mg}$ per day & & $>165 \mathrm{mg}$ per day & $>100 \mathrm{mg}$ day \\
\hline $\begin{array}{l}\text { Concurrent } \\
\text { antiplatelet } \\
\text { therapy }\end{array}$ & $\begin{array}{l}\text { Clopidogrel, } \\
\text { ticlopidine, G2b3a } \\
\text { inhibitors prohibited }\end{array}$ & $\begin{array}{l}\text { Clopidogrel } 75 \mathrm{mg} \text { daily } \\
\text { allowed }\end{array}$ & $\begin{array}{l}\text { Dual antiplatelet therapy } \\
\text { prohibited, monotherapy eligible }\end{array}$ & $\begin{array}{l}\text { Dual antiplatelet therapy (oral } \\
\text { or IV) prohibited }\end{array}$ \\
\hline $\begin{array}{l}\text { Anti- } \\
\text { inflammatory } \\
\text { agents }\end{array}$ & $\begin{array}{l}\text { NSAID with } t_{1 / 2}<12 \mathrm{~h} \\
\text { with treatment for } \\
<1 \text { week allowed }\end{array}$ & NSAID use discouraged & $\begin{array}{l}\text { NSAIDs acceptable in doses not } \\
\text { exceeding approved labeling }\end{array}$ & $\begin{array}{l}\text { Chronic use of NSAIDs, COX- } \\
1, \text { COX- } 2 \text { inhibitors } \geq 4 \text { days/ } \\
\text { week prohibited }\end{array}$ \\
\hline $\begin{array}{l}\text { Concomitant } \\
\text { therapies }\end{array}$ & N/A & $\begin{array}{l}\text { CYP-4503A4 inhibitors } \\
\text { (HIV protease } \\
\text { inhibitors, } \\
\text { ketoconazole) or } \\
\text { inducers (rifampin) } \\
\text { prohibited }\end{array}$ & $\begin{array}{l}\text { CYP-4503A4 inhibitors (azole } \\
\text { antifungals: ketoconzaole, } \\
\text { itraconazole; macrolide } \\
\text { antibiotics: clarithromycin, } \\
\text { telithromycin; protease inhibitors: } \\
\text { ritonavir, indinavir, nelfinavir, } \\
\text { atazanavir, saquinavir, } \\
\text { nefazadone) }\end{array}$ & $\begin{array}{l}\text { Treatment with P-gp inhibitors, } \\
\text { ritonavir, nelfinavir, } \\
\text { indinavir, saquinavir } \\
\text { Use of dronederone at } \\
\text { randomization } \\
\text { Systemic use with P-gp } \\
\text { inhibitors, ketoconazole, } \\
\text { itraconazole, erythromycin, } \\
\text { azithromycin, clarithromycin } \\
\text { at randomization }\end{array}$ \\
\hline $\begin{array}{l}\text { Competing } \\
\text { clinical trials or } \\
\text { investigational } \\
\text { drugs }\end{array}$ & Within last 30 days & $\begin{array}{l}\text { Within } 30 \text { days of } \\
\text { screening }\end{array}$ & Within last 30 days & $\begin{array}{l}\text { Within } 30 \text { days prior to } \\
\text { randomization }\end{array}$ \\
\hline Other & $\begin{array}{l}\text { Contraindication to } \\
\text { radio contrast, } \\
\text { chronic use of } \\
\text { corticosteroids, } \\
\text { unsuitable for follow } \\
\text { up }\end{array}$ & None & $\begin{array}{l}\text { Prisoners, psychiatric, physical } \\
\text { illness }\end{array}$ & None \\
\hline
\end{tabular}

$A L T$ alanine aminotransferase, $A S T$ aspartate aminotransferase, $C O X$ cyclo-oxygenase, $C r C l$ creatinine clearance, $C Y P-4503 A 4$ cytochrome $\mathrm{P} 450$ isoenyzme 3A4, G2b3a glycoprotein IIb/IIIa, GI gastrointestinal, IVC inferior vena cava, LMWH low-molecular weight heparin, N/A not available, NSAID non-steroidal anti-inflammatory drug, $P$-gp P-glycoprotein, $t_{1 / 2}$ half life, $U F H$ unfractionated heparin, $U L N$ upper limit of normal, VKA vitamin $\mathrm{K}$ antagonist

when possible to determine cause of death; for all other trials, cause of death was adjudicated by objective test, autopsy, documented cause, or when VTE could not be ruled out.

Exclusion criteria were similar across the studies (Table 2). Each study allowed a window for conventional parenteral anticoagulation therapy prior to enrollment with heparins or fondaparinux. Patients were excluded if life expectancy was $<3$ months (EINSTEIN-DVT, -PE; Hokusai-VTE) or $<6$ months (RE-COVER I, II, AMPLIFY) [14-19]. Patients with cancer were excluded if LMWH use was anticipated in AMPLIFY and HokusaiVTE, whereas cancer was not exclusionary in the RECOVER or EINSTEIN trials. All trials excluded patients with a $\mathrm{CrCl} \leq 30 \mathrm{~mL} / \mathrm{min}$, except AMPLIFY, which used a $\mathrm{CrCl}<25 \mathrm{~mL} / \mathrm{min}$ or a serum creatinine $>2.5 \mathrm{mg} / \mathrm{dL}$. Pregnancy excluded patients in all trials. Exclusions for high bleeding risk were better defined in RE-COVER I and
II and AMPLIFY with limitations based on hemoglobin, platelet count, recent surgery, and bleeding episodes or disorders. Only EINSTEIN allowed concomitant use of dual antiplatelet therapy.

\subsection{Bleeding Definitions}

There was concordance in the definitions of major bleeding across the trials (Table 3). The RE-COVER I and II, AMPLIFY, and Hokusai-VTE trials used the International Society of Thrombosis and Hemostasis (ISTH) definition of bleeding, while the EINSTEIN trials used a definition from the van Gogh trial that is nearly identical [26, 27]. Clinically relevant non-major (CRNM) bleeding was defined as those episodes that did not meet the criteria for major bleeding but still required medical attention (Table 3). This definition was identical in the EINSTEIN trials, AMPLIFY, and Hokusai-VTE trial [16, 17, 19, 28]. 
Table 3 Comparison of clinical trial major and clinically relevant nonmajor bleeding definitions

\begin{tabular}{|c|c|c|c|c|c|}
\hline Outcome & RE-COVER I, II ${ }^{\mathrm{a}}[14,15]$ & $\begin{array}{l}\text { EINSTEIN- } \\
\text { DVT [16] }\end{array}$ & $\begin{array}{l}\text { EINSTEIN- } \\
\text { PE [17] }\end{array}$ & $\begin{array}{l}\text { AMPLIFY } \\
{[18]}\end{array}$ & $\begin{array}{l}\text { Hokusai-VTE } \\
{[19]}\end{array}$ \\
\hline \multicolumn{6}{|l|}{ Major bleeding } \\
\hline Citation & ISTH [26] & van Gogh tri & & ISTH & \\
\hline Description & Bleeding must be symptomatic & Bleeding mu & overt & $\begin{array}{r}\text { Bleeding } \mathrm{m} \\
\text { symptoma }\end{array}$ & st be \\
\hline $\begin{array}{r}\text { Hemoglobin } \\
\text { requirement }\end{array}$ & \multicolumn{5}{|l|}{ Associated with a fall in hemoglobin of $2 \mathrm{~g} / \mathrm{dL}$ or more } \\
\hline $\begin{array}{l}\text { Transfusion } \\
\text { requirement }\end{array}$ & \multicolumn{5}{|c|}{ Leading to transfusion of $\geq 2 \mathrm{U}$ of whole blood or red cells ${ }^{\mathrm{b}}$} \\
\hline Site requirement & \multicolumn{5}{|c|}{$\begin{array}{l}\text { Critical organ (intracranial, intraspinal, intraocular, retroperitoneal, intra-articular, pericardial, intramuscular with } \\
\text { compartment syndrome) }\end{array}$} \\
\hline Mortality & \multicolumn{5}{|l|}{ Contributing to death } \\
\hline \multicolumn{6}{|c|}{ Non-major bleeding } \\
\hline Citation & Original & \multicolumn{4}{|c|}{ van Gogh trial } \\
\hline Definition & \multicolumn{5}{|l|}{ Bleeding not meeting the criteria for major bleeding } \\
\hline Intervention & $\begin{array}{l}\text { Bleeding leading to hospitalization and/or requiring } \\
\text { surgery }\end{array}$ & \multicolumn{4}{|c|}{$\begin{array}{l}\text { Associated with compromised hemodynamics, medical } \\
\text { intervention, unscheduled physician contact, cessation of } \\
\text { treatment, or associated with any other discomfort, pain, or } \\
\text { impairment of activities of daily life }\end{array}$} \\
\hline Transfusion & $\begin{array}{l}\text { Bleeding leading to transfusion of }<2 \mathrm{U} \text { of whole } \\
\text { blood or red cells }\end{array}$ & \multicolumn{4}{|l|}{ Not included } \\
\hline \multirow[t]{2}{*}{ Hematoma } & \multirow[t]{2}{*}{ Spontaneous skin hematoma of $\geq 25 \mathrm{~cm}$} & \multicolumn{4}{|c|}{$\begin{array}{l}\text { Subcutaneous hematoma }>25 \text { or }>100 \mathrm{~cm}^{2} \text { if provoked by } \\
\text { traumatic cause }\end{array}$} \\
\hline & & \multicolumn{4}{|c|}{ Intramuscular hematoma documented by ultrasonography } \\
\hline Epistaxis & Nose bleed $>5$ min duration & \multicolumn{4}{|c|}{ Epistaxis $>5 \mathrm{~min}$, if it is repetitive, or leads to intervention } \\
\hline Gingival & Gingival bleeding $>5$ min duration & \multicolumn{4}{|c|}{$\begin{array}{l}\text { Gingival bleeding if it occurs spontaneously, or it lasts for } \\
>5 \mathrm{~min}\end{array}$} \\
\hline Hematuria & \multicolumn{5}{|c|}{ Macroscopic hematuria, either spontaneous or lasts for $>24 \mathrm{~h}$ after instrumentation, or of the urogenital tract } \\
\hline Gastrointestinal & Not included & \multicolumn{4}{|c|}{$\begin{array}{l}\text { Macroscopic gastrointestinal hemorrhage, including at least } 1 \\
\text { episode of melena or hematemesis, or rectal blood loss }\end{array}$} \\
\hline Rectal & \multicolumn{5}{|c|}{ Spontaneous rectal bleeding (more than blood spots on toilet paper) } \\
\hline Hemoptysis & Undefined & \multicolumn{4}{|c|}{$\begin{array}{l}\text { Hemoptysis if more than a few speckles in the sputum and not } \\
\text { occurring within context of pulmonary embolism }\end{array}$} \\
\hline Other & $\begin{array}{l}\text { Any bleeding considered clinically relevant by } \\
\text { investigator }\end{array}$ & \multicolumn{4}{|l|}{ Not included } \\
\hline
\end{tabular}

a For RE-COVER I and II at least one of the criteria had to be fulfilled

b Red cell unit corresponds to $500 \mathrm{~mL}$ of whole blood

ISTH International Society of Thrombosis and Hemostasis

In the RE-COVER I and II trials, the definition of CRNM bleeding was more stringent, requiring hospitalization and/ or surgery, and transfusion of $<2 \mathrm{U}$ of whole blood or red cells. It did not include parameters for hemoptysis and gastrointestinal bleeding [14, 15]. The RE-COVER I and II trials also included an option that allowed the investigator to designate these events.

\subsection{Assessment of Non-Inferiority}

All of the acute VTE treatment trials with the NOACs have had the primary efficacy outcome of non-inferiority compared with standard therapy. Non-inferiority studies are designed to show that a treatment is 'as good as' current therapy, and are commonly employed when the use of placebo would be unethical. Non-inferiority margins must be chosen in a manner that considers both the uncertainty associated with the estimated treatment benefit and a tolerable margin for similarity between the tested and established therapy. A narrower margin is a reflection of greater certainty that the finding by the non-inferiority testing is true, and is also partly a reflection of sample size.

While each of these agents demonstrated non-inferiority in their respective trials, the definition of non-inferiority was not consistent between the trials. The RE-COVER trials had the highest boundaries for non-inferiority, with 
the hazard ratio (HR) for non-inferiority being out to 2.75 . The outer $95 \%$ confidence interval (CI) achieved with dabigatran was 1.84 and 1.80 in the RE-COVER I and II trials, respectively, and 1.57 in the pooled analysis $[14,15]$. In the EINSTEIN trials, the definition of non-inferiority was an HR of 2.0. In the EINSTEIN-DVT trial, the outer $95 \% \mathrm{CI}$ achieved with rivaroxaban was 1.04 , and was 1.68 in the EINSTEIN-PE trial $[16,17]$. In the pooled analysis of the EINSTEIN trials, the HR for non-inferiority was 1.75 and the upper $95 \% \mathrm{CI}$ achieved with rivaroxaban was 1.19 [29]. In the more recent AMPLIFY and Hokusai-VTE trials, the non-inferiority margins were decreased to a relative risk (RR) of 1.80 and an HR of 1.50, respectively [18, 19]. The upper $95 \% \mathrm{CI}$ achieved with apixaban was 1.18 and was 1.13 with edoxaban. The broad definition of noninferiority in the RE-COVER and EINSTEIN trials may cause clinicians to question the utility of the efficacy outcome results. While the upper $95 \%$ CI boundary in the EINSTEIN-PE trial may raise questions, the HR and $95 \%$ $\mathrm{CI}$ in the pooled analysis provides some support to the efficacy of rivaroxaban, which was approved for treatment of acute VTE and prevention of recurrent events by the FDA in 2012. In addition, dabigatran was just recently approved for this indication in early 2014. The more conservative non-inferiority boundaries in the apixaban and edoxaban trials are less likely to be a concern in regards to approval by the FDA.

\section{Acute Treatment Clinical Trial Results}

Demographics for patients in the individual trials are detailed in Table 4. Efficacy and safety outcomes are presented in Table 5.

\subsection{Dabigatran Etexilate}

The RE-COVER I $(n=2,564)$ and II $(n=2,589)$ trials shared a similar design $[14,15]$. Patients were randomized to dabigatran $150 \mathrm{mg}$ twice daily or warfarin to a

Table 4 Comparison of patient characteristics in acute venous thromboembolism trials

\begin{tabular}{|c|c|c|c|c|c|c|}
\hline Characteristic & $\begin{array}{l}\text { RE-COVER } \\
\text { I [14] }\end{array}$ & $\begin{array}{l}\text { RE-COVER } \\
\text { II [15] }\end{array}$ & $\begin{array}{l}\text { EINSTEIN- } \\
\text { DVT [16] }\end{array}$ & $\begin{array}{l}\text { EINSTEIN- } \\
\text { PE [17] }\end{array}$ & $\begin{array}{l}\text { AMPLIFY } \\
{[18]}\end{array}$ & $\begin{array}{l}\text { Hokusai- } \\
\text { VTE [19] }\end{array}$ \\
\hline Patients $(n)$ & 2,539 & 2,568 & 3,449 & 4,832 & 5,395 & 8,240 \\
\hline Mean age (years) & 55 & $57^{\mathrm{a}}$ & 56 & 58 & 57 & 56 \\
\hline Male sex $(\%)$ & 58 & 61 & 57 & 53 & 59 & 57 \\
\hline Mean weight (kg) & 85 & 83 & 82 & 83 & 85 & 82 \\
\hline $\mathrm{CrCl} 30-50 \mathrm{~mL} / \mathrm{min}(\%)$ & 4.7 & 4.9 & 6.8 & 8.2 & 5.7 & 6.6 \\
\hline \multicolumn{7}{|l|}{ Index event $(\%)$} \\
\hline Patients with DVT only & 68.9 & 68.1 & 98.7 & 0 & 65.5 & 59.7 \\
\hline Patients with PE only & 21.3 & 23.2 & 0 & 75.2 & 25.2 & 30.4 \\
\hline Patients with PE and DVT & 9.6 & 8.6 & 0.1 & 24.8 & 8.8 & 9.9 \\
\hline Unprovoked VTE (\%) & NR & NR & 62.0 & 64.5 & 89.8 & 65.7 \\
\hline Patients with active cancer $(\%)$ & 4.8 & 3.9 & 6.0 & 4.6 & 2.7 & 2.5 \\
\hline History of VTE (\%) & 25.6 & 17.5 & 19.3 & 19.5 & 16.2 & 18.4 \\
\hline $\begin{array}{l}\text { Median duration of parenteral anticoagulation in } \\
\text { the VKA group (days) }\end{array}$ & $9^{\mathrm{a}}$ & 10 & 8 & 8 & 6.5 & 7 \\
\hline $\begin{array}{l}\text { Patients receiving parenteral anticoagulation in the } \\
\text { NOAC group }(\%)\end{array}$ & 100 & 100 & 73 & 93 & 86 & 100 \\
\hline $\begin{array}{l}\text { Median duration of parenteral anticoagulation in } \\
\text { the NOAC group (days) }\end{array}$ & $9^{\mathrm{b}}$ & 9 & 1 & 1 & 1 & 7 \\
\hline \multicolumn{7}{|l|}{ INR control ${ }^{\mathrm{c}}$} \\
\hline TTR $\left[\%\left(\right.\right.$ range $\left.\left.^{\mathrm{d}}\right)\right]$ & $60(53-66)$ & $57(51-62)$ & $58(54-66)$ & $63(58-73)$ & $61(\mathrm{NR})$ & 64 (NR) \\
\hline$\%$ above INR of 3.0 & 19 & 19 & 16 & 16 & 16 & 18 \\
\hline$\%$ below INR of 2.0 & 21 & 24 & 24 & 22 & 23 & 19 \\
\hline
\end{tabular}

$\mathrm{CrCl}$ creatinine clearance, $D V T$ deep vein thrombosis, INR international normalized ratio, NOAC novel oral anticoagulant, $N R$ not reported, $P E$ pulmonary embolism, TTR time in therapeutic range, VKA vitamin $\mathrm{K}$ antagonist, VTE venous thromboembolism

a Median reported instead of mean

b Total duration before and after randomization

c For patients randomized to vitamin K antagonist therapy

d Represents the time in therapeutic range during the first month of therapy compared with the end of the trial 


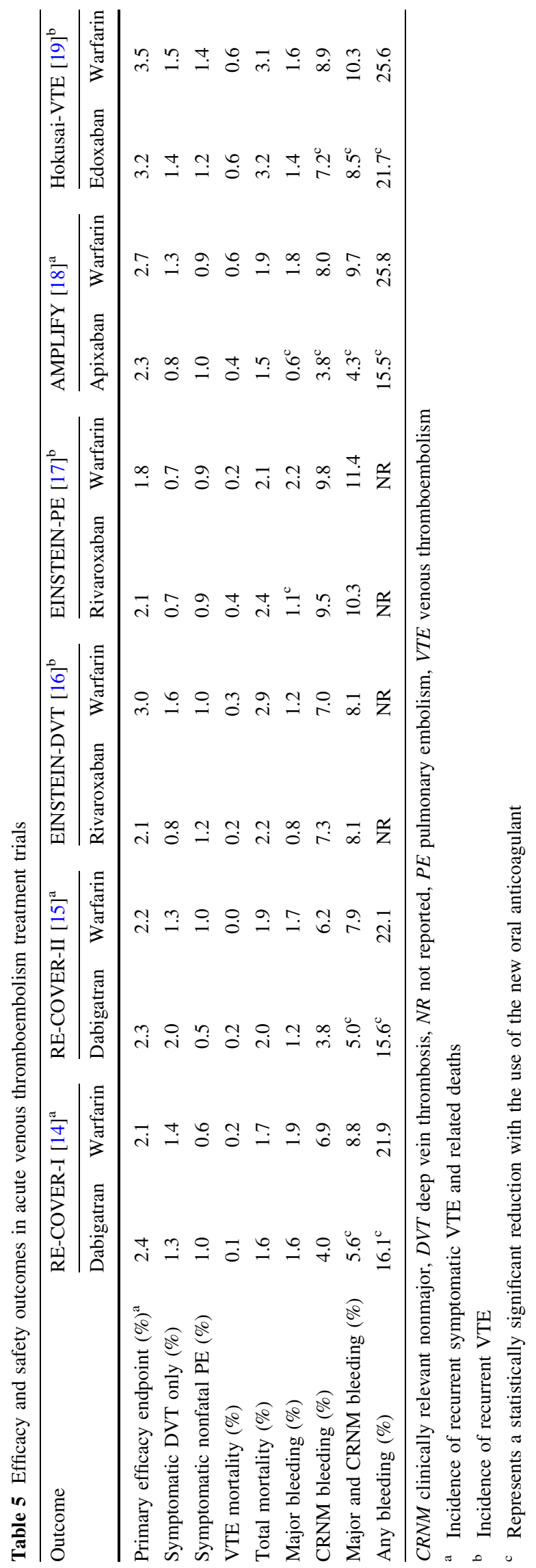

therapeutic INR (2.0-3.0). All patients received initial therapy with an injectable anticoagulant for a median of 9 days. In both trials, dabigatran was non-inferior to warfarin in the prevention of the primary endpoint (RECOVER I: HR 1.10; $95 \%$ CI 0.65-1.84; $p<0.001$; RECOVER II: HR 1.08; $95 \%$ CI $0.64-1.8 ; p<0.001$ ) (Table 5). Major bleeding was not significantly different between the groups (HR 0.82; $95 \%$ CI $0.45-1.48$ ), but there was a significant $36 \%$ relative reduction (HR 0.63 ; $95 \%$ CI $0.47-0.84 ; p=0.002)$ in RE-COVER I and a $38 \%$ relative reduction in the combination of major and CRNM bleeding with the use of dabigatran compared with warfarin (HR 0.62; $95 \%$ CI 0.45-0.84) in RE-COVER II (Table 5). While all other adverse effects were similar between the groups, patients receiving dabigatran were more likely to experience dyspepsia during the study compared with patients receiving warfarin (2.9 vs $0.6 \%$; $p<0.001)$ in RE-COVER I. There was no difference in events leading to the discontinuation of study drug between the groups in RE-COVER II. Due to the shared trial design and defined endpoints, a pooled analysis of 5,107 patients from the RE-COVER I and II trials was completed [15]. In this combined analysis, dabigatran maintained its noninferiority to standard of care in terms of the primary efficacy outcome (2.4 vs $2.2 \%$; HR $1.09 ; 95 \%$ CI $0.76-1.57 ; p<0.001$ for non-inferiority). The incidence of major bleeding was not significantly different between the dabigatran and warfarin groups (1.4 vs $2.0 \%$; HR 0.73 ; $95 \%$ CI $0.48-1.11$ ), but there was a significant reduction in the combination of major bleeding and CRNM bleeding (5.3 vs $8.5 \%$; HR 0.62 ; $95 \%$ CI $0.50-0.76$ ) and with any bleeding (HR 0.70; $95 \%$ CI 0.61-0.79) [15]. Furthermore, when bleeding events are compared from the start of the oral study drug only, there is a significant reduction in major bleeding (HR 0.60; $95 \%$ CI 0.36-0.99), major or CRNM bleeding (HR 0.56; $95 \%$ CI 0.45-0.71), and any bleeding (HR 0.67; $95 \%$ CI 0.59-0.77) favoring dabigatran [15].

\subsection{Rivaroxaban}

In the EINSTEIN-DVT trial, patients $(n=3,449)$ were randomized to rivaroxaban $15 \mathrm{mg}$ twice daily for 21 days followed by $20 \mathrm{mg}$ once daily or traditional therapy with enoxaparin $1 \mathrm{mg} / \mathrm{kg}$ twice daily and a VKA to an INR of 2.0-3.0 [16]. Patients randomized to conventional therapy had a median duration of parenteral treatment of 8 days. In the EINSTEIN-DVT trial, patients receiving rivaroxaban demonstrated a $30 \%$ relative reduction in the primary endpoint compared with standard of care (HR 0.68; $95 \%$ CI 0.44-1.04) (Table 5). This met the trial's qualifications for non-inferiority $(p<0.001)$ but not for superiority $(p=0.08)$ [16]. The primary safety outcome (composite of 
major or CRNM bleeding) occurred in $8.1 \%$ of patients in both groups, with a numerical decrease in major bleeding and an increase in CRNM bleeding with the use of rivaroxaban compared with standard of care (Table 5). Net clinical benefit, which included the combination of the primary efficacy outcome and major bleeding, was also a prespecified outcome. Net clinical benefit favored rivaroxaban compared with standard of care (2.9 vs $4.2 \%$; $p=0.03$ ) [16].

In the EINSTEIN-PE trial, patients $(n=4,833)$ were randomized to rivaroxaban and conventional therapy, as in the EINSTEIN-DVT trial [17]. Patients randomized to conventional therapy had a median duration of parenteral treatment of 8 days. The EINSTEIN-PE trial also demonstrated the non-inferiority of rivaroxaban compared with warfarin (HR 1.12; $95 \%$ CI 0.75-1.68) (Table 6). In this trial, major bleeding was significantly reduced by $50 \%$ with the use of rivaroxaban compared with standard of care (HR 0.49; $95 \%$ CI $0.31-0.79 ; p=0.003$ ). The incidence of CRNM bleeding or the combination of major and CRNM bleeding were similar between the groups
(Table 5). Net clinical benefit was not different between the groups in the EINSTEIN-PE trial (3.4 vs $4.0 \%$; $p=0.28$ ) [17].

Due to the shared trial design and defined endpoints, a combined analysis of the EINSTEIN-DVT and EINSTEINPE trials was conducted [29]. In this combined analysis of 8,282 patients, rivaroxaban $(2.1 \%)$ maintained its noninferiority to standard of care $(2.3 \%)$ in terms of the primary efficacy outcome (HR 0.89; $95 \%$ CI 0.66-1.19; $p<0.001$ for non-inferiority), but was not superior $(p=0.41)$. While there was no difference in the incidence of major and CRNM bleeding (9.4 vs $10.0 \% ; p=0.27$ ), there was a $>45 \%$ relative reduction in major bleeding with the use of rivaroxaban compared with standard of care ( 1.0 vs $1.7 \% ; p=0.002$ ). This reduction in major bleeding drove the significant reduction on net clinical benefit of rivaroxaban over standard of care (HR 0.77; $95 \% \mathrm{CI}$ 0.61-0.97). Patients presenting with a history of VTE in the EINSTEIN trials demonstrated a significant $55 \%$ reduction in recurrent VTE with rivaroxaban use compared with standard of care (1.4 vs $3.1 \%$; HR $0.45 ; 95 \%$ CI

Table 6 Comparison of patient characteristics in long-term secondary venous thromboembolism prevention trials

\begin{tabular}{|c|c|c|c|c|c|}
\hline \multirow[t]{2}{*}{ Characteristic } & \multirow{2}{*}{$\begin{array}{l}\text { RE-MEDY } \\
{[30]} \\
\text { Dabigatran }\end{array}$} & \multirow{2}{*}{$\begin{array}{l}\text { RE-SONATE } \\
{[30]} \\
150 \mathrm{mg} \text { bid }\end{array}$} & \multirow{2}{*}{$\begin{array}{l}\text { EINSTEIN-Extension [16] } \\
\text { Rivaroxaban } 20 \mathrm{mg} \text { daily }\end{array}$} & \multicolumn{2}{|c|}{ AMPLIFY-EXT [28] } \\
\hline & & & & $\begin{array}{l}\text { Apixaban } \\
2.5 \mathrm{mg} \text { bid }\end{array}$ & $\begin{array}{l}\text { Apixaban } \\
5 \mathrm{mg} \text { bid }\end{array}$ \\
\hline Patients $(n)$ & 1,430 & 681 & 602 & 840 & 813 \\
\hline Mean age (years) & 55.4 & 56.1 & 58.2 & 56.6 & 56.4 \\
\hline Male sex $(\%)$ & 60.9 & 55.9 & 58.8 & 58 & 57.7 \\
\hline Mean weight (kg) & 86.1 & 83.7 & 82.2 & 85.7 & 85.7 \\
\hline $\mathrm{CrCl}<30 \mathrm{~mL} / \mathrm{min}(\%)$ & 0 & NR & 0 & 0.1 & 0.4 \\
\hline $\mathrm{CrCl} 30-50 \mathrm{~mL} / \mathrm{min}(\%)$ & 4.1 & 6.0 & 6.1 & 5.6 & 5.0 \\
\hline Patients with DVT (\%) & 65.6 & 63.3 & 64.1 & 64.8 & 64.8 \\
\hline Patients with PE (\%) & 22.7 & 26.9 & 35.9 & 35.2 & 35.2 \\
\hline Patients with PE and DVT (\%) & 11.7 & 6.9 & NR & NR & NR \\
\hline Unprovoked VTE (\%) & NR & NR & 73.1 & 93.2 & 90.7 \\
\hline Patients with active cancer (\%) & 4.2 & $0.1^{\mathrm{a}}$ & 4.7 & 1.8 & 1.1 \\
\hline History of VTE (\%) & NR & NR & 17.9 & 11.8 & 14.5 \\
\hline $\begin{array}{l}\text { Mean treatment duration before } \\
\text { randomization (days) }\end{array}$ & 198 & 293 & $\begin{array}{l}\text { NR } \\
\text { VKA pre-treatment } 6-12 \text { months: } \\
429(71.3 \%) \\
\text { Rivaroxaban pre-treatment } \\
6-12 \text { months: } 173(28.7 \%)\end{array}$ & NR & NR \\
\hline Mean duration of study drug (days) & 473 & 165 & $\begin{array}{l}\text { NR } \\
\text { Median } 181 \text { days- } 6 \text { months } \\
\text { Median } 264 \text { days-12 months }\end{array}$ & $\begin{array}{l}\mathrm{NR} \\
2(0.2 \%)<6 \\
828(98.6 \% \\
10(1.2 \%)>\end{array}$ & $\begin{array}{l}\text { onths } \\
-12 \text { months } \\
\text { months }\end{array}$ \\
\hline
\end{tabular}

bid twice daily, $\mathrm{CrCl}$ creatinine clearance, $\mathrm{DVT}$ deep vein thrombosis, $N R$ not reported, $P E$ pulmonary embolism, $V K A$ vitamin $\mathrm{K}$ antagonist, $V T E$ venous thromboembolism

${ }^{a}$ active cancer was an exclusion criterion, and the numbers represent protocol violations 
0.22-0.91) with similar rates of major bleeding (HR 0.51; 95\% CI 0.21-1.27) [29].

Patients enrolled in EINSTEIN-DVT had slightly higher rates of recent surgery, trauma, and active cancer compared with patients enrolled in EINSTEIN-PE [16, 17]. Patients with recent surgery or trauma equaled $19.5 \%$ of the patients receiving rivaroxaban and $19.5 \%$ of the patients receiving enoxaparin/VKA in EINSTEIN-DVT compared with $17.2 \%$ of the patients receiving rivaroxaban and $16.5 \%$ of the patients receiving enoxaparin/VKA in EINSTEIN-PE. Patients with cancer made up 6.8 and $5.2 \%$ of the patients receiving rivaroxaban and enoxaparin/VKA, respectively, in EINSTEIN-DVT in contrast to 4.7 and $4.5 \%$ for rivaroxaban and enoxaparin/VKA, respectively, in EINSTEIN-PE. Statistically, these numbers were not different in the pooled analysis [29]; however, it is possible that the higher prevalence of cancer and surgery or trauma may have predisposed the EINSTEIN-DVT population towards more bleeding.

\subsection{Apixaban}

In the AMPLIFY trial, patients $(n=5,395)$ were randomized to apixaban $10 \mathrm{mg}$ twice daily for 7 days followed by apixaban $5 \mathrm{mg}$ twice daily or injectable anticoagulant followed by warfarin titrated to an INR of 2.0 to 3.0. Patients randomized to conventional therapy had a median duration of parenteral treatment of 6.5 days. Patients randomized to apixaban had a $16 \%$ relative reduction in the primary endpoint compared with standard of care (RR 0.84; $95 \%$ CI 0.60-1.18) (Table 5) [18]. This met the trial's qualifications for non-inferiority $(p<0.001)$ but not for superiority. Apixaban demonstrated similar efficacy in the $66 \%$ of patients enrolled with DVT (2.2 vs $2.7 \%$; RR $0.83 ; 95 \%$ CI $0.54-1.26)$ and the $34 \%$ of patients enrolled with PE (2.3 vs $2.6 \%$; RR 0.90; $95 \%$ CI 0.50-1.61) compared with standard of care. Major bleeding was significantly reduced by over $65 \%$ with the use of apixaban compared with standard of care (RR $0.31 ; 95 \%$ CI 0.17-0.55). There were also significant reductions in CRNM bleeding and major or CRNM bleeding with the use of apixaban (Table 5). Net clinical benefit significantly favored treatment with apixaban compared with standard of care (2.8 vs $4.5 \% ; p=0.001)$ [18]

\subsection{Edoxaban}

In the Hokusai-VTE trial, patients ( $n=8,292)$ were randomized to edoxaban $60 \mathrm{mg}$ once daily or warfarin titrated to an INR of 2.0 to 3.0 [19]. Among those randomized to receive edoxaban, $733(17.8 \%)$ received a reduced dose of $30 \mathrm{mg}$ once daily while the remainder received $60 \mathrm{mg}$ once daily. Patients in both groups had a median duration of parenteral treatment of 7 days. Patients receiving edoxaban in the Hokusai-VTE trial demonstrated an $11 \%$ relative reduction in the incidence of the primary efficacy endpoint (HR 0.89; $95 \%$ CI 0.70-1.13) (Table 5). This met the trial's qualifications for non-inferiority $(p<0.001)$ but not for superiority [19]. Among the $40 \%$ of patients enrolled with PE, edoxaban seemed to have a signal of improved efficacy compared with warfarin (2.8 vs $3.9 \%$; HR 0.73 ; $95 \%$ CI 0.50-1.06), while in the $60 \%$ of patients enrolled with DVT, efficacy was equivalent to warfarin (3.4 vs $3.3 \%$; HR 1.02; $95 \%$ CI $0.75-1.38)$. The primary safety outcome (major or CRNM bleeding) was significantly reduced with the use of edoxaban compared with warfarin (HR 0.81; $95 \%$ CI 0.71-0.94; $p=0.004$ ) [19]. Major bleeding was not significantly reduced with the use of edoxaban, while CRNM $(p=0.004)$ and any bleeding $(p<0.001)$ were lower compared with warfarin (Table 5). The edoxaban 30-mg once-daily dose maintained efficacy (HR 0.73; $95 \%$ CI 0.42-1.26) and preserved safety (HR $0.62 ; 95 \%$ CI 0.44-0.86) compared with warfarin therapy [19].

\section{Extended Secondary Prevention Trials}

Demographics for patients in the individual trials are detailed in Table 6. Efficacy and safety outcomes are presented in Table 7.

\subsection{Dabigatran}

The safety and efficacy of dabigatran for long-term secondary prevention of VTE has been evaluated in two trials, which enrolled patients with objectively confirmed symptomatic proximal DVT or PE who completed at least 3 months of treatment with warfarin or dabigatran [30]. Patients in the RE-MEDY (Secondary Prevention of Venous ThromboEmbolism) trial were considered to still be at risk of recurrent VTE and were therefore randomized in a double-blinded fashion to dabigatran $150 \mathrm{mg}$ twice daily or active control with warfarin to an INR of 2.0-3.0 for 6-36 months (mean 15.8 months) [30]. In the RESONATE (Twice-daily Oral Direct Thrombin Inhibitor Dabigatran Etexilate in the Long Term Prevention of Recurrent Symptomatic VTE) trial, investigators had to have equipoise regarding the need for continued anticoagulant therapy. Patients in the RE-SONATE trial were randomized to dabigatran $150 \mathrm{mg}$ twice daily or placebo for up to 12 months (mean 5.5 months) [30]. Of the 2,856 patients in the RE-MEDY trial, $40 \%$ were initially enrolled in the RE-COVER I or II trials, while only $2 \%$ of the 1,343 patients in the RE-SONATE trial had been enrolled in these trials. The primary efficacy outcome was 
Table 7 Comparison of efficacy and safety outcomes in long-term secondary venous thromboembolism prevention trials

\begin{tabular}{|c|c|c|c|c|c|c|c|c|c|}
\hline \multirow[t]{2}{*}{ Outcome } & \multicolumn{2}{|c|}{ RE-MEDY [30] } & \multicolumn{2}{|c|}{ RE-SONATE [30] } & \multicolumn{2}{|c|}{$\begin{array}{l}\text { EINSTEIN-Extension } \\
{[16]}\end{array}$} & \multicolumn{3}{|c|}{ AMPLIFY-EXT [28] } \\
\hline & $\begin{array}{l}\text { Dabigatran } \\
150 \mathrm{mg} \mathrm{bid}\end{array}$ & Warfarin & $\begin{array}{l}\text { Dabigatran } \\
150 \mathrm{mg} \text { bid }\end{array}$ & Placebo & $\begin{array}{l}\text { Rivaroxaban } \\
20 \text { mg daily }\end{array}$ & Placebo & $\begin{array}{l}\text { Apixaban } \\
2.5 \mathrm{mg} \text { bid }\end{array}$ & $\begin{array}{l}\text { Apixaban } \\
5 \mathrm{mg} \text { bid }\end{array}$ & Placebo \\
\hline Primary endpoint (\%) & 1.8 & 1.3 & $0.4^{\mathrm{a}}$ & 5.6 & $1.3^{\mathrm{a}}$ & 7.1 & $3.8^{\mathrm{a}}$ & $4.2^{\mathrm{a}}$ & 11.6 \\
\hline Symptomatic DVT only (\%) & 1.2 & 0.9 & 0.3 & 3.3 & 0.8 & 5.2 & 0.7 & 1.0 & 6.4 \\
\hline Symptomatic nonfatal PE (\%) & 0.7 & 0.4 & 0.1 & 2.1 & 0.3 & 2.2 & 1.0 & 0.5 & 1.8 \\
\hline VTE mortality (\%) & 0.1 & 0.1 & 0 & 0 & 0.2 & 0.2 & 0.2 & 0.4 & 0.8 \\
\hline Total mortality (\%) & 1.2 & 1.3 & 0 & 0.3 & 0.2 & 0.3 & 0.8 & 0.5 & 1.7 \\
\hline Major bleeding (\%) & 0.9 & 1.8 & 0.3 & 0.0 & 0.7 & 0.0 & 0.2 & 0.1 & 0.5 \\
\hline CRNM bleeding (\%) & 4.7 & 8.4 & 5.0 & 1.8 & 5.4 & 1.2 & 3.0 & $4.2^{\mathrm{b}}$ & 2.3 \\
\hline $\begin{array}{l}\text { Major and CRNM } \\
\text { bleeding }(\%)\end{array}$ & $5.6^{\mathrm{a}}$ & 10.2 & $5.3^{\mathrm{b}}$ & 1.8 & $6.0^{\mathrm{b}}$ & 1.2 & 3.2 & 4.3 & 2.7 \\
\hline Any bleeding $(\%)$ & $19.4^{\mathrm{a}}$ & 26.2 & $10.5^{\mathrm{b}}$ & 5.9 & $17.4^{\mathrm{b}}$ & 10.7 & NR & NR & NR \\
\hline
\end{tabular}

bid twice daily, CRNM clinically relevant nonmajor, $D V T$ deep vein thrombosis, $N R$ not reported, $P E$ pulmonary embolism, VTE venous thromboembolism

a Represents a statistically significant reduction with the use of the new oral anticoagulant

b Represents a statistically significant increase with the use of the new oral anticoagulant

the incidence of recurrent, objectively confirmed symptomatic VTE or VTE-related death. The RE-MEDY trial was designed as a non-inferiority trial, while the RESONATE trial was designed to demonstrate superiority of dabigatran [30]. Bleeding outcomes included major and CRNM bleeding using the same definitions as the RECOVER I and II trials.

In the active-control RE-MEDY trial, dabigatran demonstrated non-inferiority $(p=0.01)$ compared with warfarin for the primary efficacy endpoint (HR 1.44; $95 \%$ CI 0.78-2.64) (Table 7). While major bleeding was reduced by $50 \%$ with dabigatran compared with warfarin, it did not achieve statistical significance $(p=0.06)$. As in the RECOVER trials, major or CRNM bleeding was significantly lower with the use of dabigatran compared with warfarin (HR 0.54; $95 \%$ CI 0.41-0.71). There was also an increased risk in the incidence of acute coronary syndrome (ACS) in patients randomized to dabigatran in this trial $(0.9$ vs $0.2 \% ; p=0.02)[30]$.

In the placebo-controlled RE-SONATE trial, dabigatran demonstrated a significant $92 \%$ reduction in the primary endpoint, representing superiority over placebo (HR 0.08; $95 \%$ CI 0.02-0.25) (Table 7). While major bleeding was not significantly increased with the use of dabigatran, there were significant increases in both major or CRNM bleeding (HR $2.92 ; 95 \%$ CI 1.52-5.60) and any bleeding (HR 1.82; $95 \%$ CI 1.23-2.68) with the use of dabigatran compared with placebo (Table 7). The incidence of ACS was not different between the groups $(0.1$ vs $0.2 \%)$. Although there was a difference in the incidence of ACS in the active-control REMEDY trial, this may reflect a protective effect of warfarin more than than a harmful effect of dabigatran [30].

\subsection{Rivaroxaban}

The long-term use of rivaroxaban for secondary prevention of VTE was evaluated in the EINSTEIN-Extension trial [16]. Patients with objectively confirmed, symptomatic VTE who had completed treatment of 6-12 months with a VKA or rivaroxaban were randomized in a double-blinded fashion to rivaroxaban $20 \mathrm{mg}$ once daily or placebo for an additional $6(60 \%)$ to $12(40 \%)$ months. Randomization to placebo was considered ethical as investigators had to have equipoise with respect to the need for continued anticoagulant therapy. Of the 1,196 patients in the EINSTEIN-Extension trial, $34.1 \%$ were initially enrolled in the EINSTEIN-DVT trial and $19.1 \%$ were in the EINSTEIN-PE trial [16]. At the time of randomization, $72 \%$ of patients had completed treatment with a VKA and $28 \%$ with rivaroxaban for a median of approximately 7 months. The primary efficacy outcome of recurrent symptomatic VTE was significantly reduced by $82 \%$ with the use of rivaroxaban compared with placebo (HR 0.18; $95 \% \mathrm{CI}$ 0.09-0.39) (Table 7). While the primary safety outcome of major bleeding was not different between the groups, there was a significant increase in major or CRNM bleeding with the use of rivaroxaban compared with placebo (HR 5.19; $95 \%$ CI 2.3-11.7) (Table 7). This increase was mainly due to increases in hematuria ( 9 vs 0 events), epistaxis ( 8 vs 1 event), and rectal bleeding (7 vs 2 events) [16].

\subsection{Apixaban}

Apixaban was evaluated for long-term prevention of VTE in the AMPLIFY-EXT (AMPLIFY-Extended Treatment) 
trial [28]. Patients with objectively confirmed symptomatic VTE who had completed 6-12 months with warfarin or apixaban were randomized in a double-blinded fashion to apixaban $2.5 \mathrm{mg}$ twice daily, apixaban $5 \mathrm{mg}$ twice daily, or placebo for an additional 12 months. As in the EINSTEINExtension trial, investigators had to have equipoise with respect to the need for continued anticoagulant therapy. Of the 2,482 patients in the AMPLIFY-EXT trial, $33.7 \%$ were initially enrolled in the AMPLIFY trial. The primary efficacy outcome of recurrent symptomatic VTE or death from any cause was significantly reduced by $67 \%$ with apixaban $2.5 \mathrm{mg}$ twice daily (RR 0.33 ; $95 \%$ CI $0.22-0.48$ ) and $64 \%$ with apixaban $5 \mathrm{mg}$ twice daily (RR $0.36 ; 95 \%$ CI 0.25-0.53) compared with placebo (Table 7) [28]. When the primary outcome from the AMPLIFY trial is used (recurrent symptomatic VTE or VTE-related death), both apixaban groups demonstrated an $80 \%$ reduction compared with placebo (1.7\% for both groups vs $8.8 \%$; $p<0.001)$. These results suggest that, after the initial treatment period for acute VTE, an even lower dose may be able to be used for long-term secondary prevention of VTE. The rate of CRNM bleeding was higher in the apixaban 2.5-mg twice-daily group (RR 1.29; $95 \%$ CI $0.72-2.33$ ), but was only significantly higher in the apixaban 5-mg twice-daily group compared with placebo (RR 1.82; $95 \%$ CI 1.05-3.18) [32]. As with rivaroxaban, most of the increase in CRNM bleeding was due to numerical increases in hematuria, epistaxis, and rectal bleeding. There was no difference between the two apixaban doses for efficacy or safety (Table 7).

\section{Subpopulations}

Several specific subpopulations were represented in these acute VTE treatment trials. Standard of care for the acute treatment of VTE in patients with cancer is different from that in patients without cancer. In patients with cancer, treatment of VTE with a LMWH for 3-6 months has demonstrated better efficacy than and similar safety to treatment with an injectable anticoagulant transitioned over to warfarin for a similar duration. Based on these data, acute treatment of VTE in patients with cancer with a LMWH for 3-6 months is recommended in most clinical guidelines [8, 31, 32]. Patients with active cancer were included in all of the acute VTE treatment trials of the NOACs. The percent of patients with active cancer in these trials was low, ranging from $2.5 \%$ in the Hokusai-VTE trial to $6.0 \%$ in the EINSTEIN-DVT trial (Table 5) [18, 19]. While the overall percentage of patients with active cancer in these trials was small, there were 430 patients with active cancer in the EINSTEIN trials and over 1,000 patients with active cancer enrolled collectively in these trials. The largest LMWH trial for prevention of VTE in patients with active cancer had only 672 randomized patients [33]. VTE and bleeding rates were higher in patients with active cancer compared with those without active cancer [14-19]. In each of these trials, the primary efficacy outcome was numerically lower in the NOAC group compared with the standard of care group in patients with active cancer $(3.5 \%$ dabigatran vs $4.7 \%$ warfarin; $5.1 \%$ rivaroxaban vs $7.1 \%$ VKA; $3.7 \%$ edoxaban vs $7.1 \%$ warfarin; not reported in AMPLIFY) [18, 19, 29]. A recent meta-analysis of dabigatran, rivaroxaban, and apixaban studies suggests that these NOACs have the same efficacy and safety as conventional treatment for patients with cancer, and no difference in efficacy and safety was observed between patients with and without cancer [34]. Although these data may give some reassurance in the use of these new agents compared with warfarin, until a trial evaluating the NOACs compared with LMWH in cancer is conducted, LMWH should remain the treatment of choice. The American Society of Clinical Oncology Clinical Practice Guidelines, based on informal consensus, do not support the use of NOACs for either VTE prevention or treatment [34]. Similarly, the National Comprehensive Cancer Network Clinical Practice Guidelines for Venous Thromboembolic Disease recognizes rivaroxaban and apixaban, but they are not included among the recommendations for acute treatment or secondary VTE prevention [35]. There are patients who do not receive LMWH due to the cost of 3-6 months of therapy, and it is unlikely that the NOACs will provide a significant advantage in this regard. Until appropriate clinical trials are conducted, only patients with active cancer who refuse to receive subcutaneous injections and will not comply with warfarin therapy restrictions or monitoring should be considered candidates for NOAC treatment of their VTE event.

The EINSTEIN and Hokusai-VTE trials also looked at outcomes in fragile patients, which are patients with $\mathrm{CrCl}$ $\leq 50 \mathrm{~mL} / \mathrm{min}$, age $\geq 75$ years of age, and body weight $\leq 50 \mathrm{~kg}$. In the pooled analysis of the EINSTEIN trials, 1,573 patients were considered fragile, while there were 1,421 in the Hokusai-VTE trial. No differences were noted in efficacy of rivaroxaban compared with standard of care in fragile patients compared with non-fragile patients (HR 0.68 ; $95 \%$ CI $0.39-1.18$ ). As might be expected, major bleeding was higher in fragile patients $(p=0.01$ for interaction) [29]. However, there was a significant (73\%) relative reduction in major bleeding with the use of rivaroxaban compared with standard of care in these fragile patients ( 1.3 vs $4.5 \%$; HR 0.27 ; $95 \%$ CI $0.13-0.54$ ). This reduction in major bleeding was consistent for all of the groups that made up the fragile patient subgroup (older age [1.2 vs $4.5 \%$ ], reduced $\mathrm{CrCl}$ [0.9 vs $4.1 \%$ ], and light body weight [0 vs $4.6 \%$ ]). Conversely, the rate of recurrent VTE 
in fragile patients receiving edoxaban compared with standard of care favored edoxaban, and this was not observed in non-fragile patients $(p=0.408)$. No significant difference was noted in the rates of clinically relevant bleeding between fragile and non-fragile patients receiving edoxaban compared with standard of care [19].

All of the NOACs have some degree of renal elimination. A reduction in $\mathrm{CrCl}$ ranging from $<25$ to $<30 \mathrm{~mL} / \mathrm{min}$ was among exclusion criteria for the VTE treatment trials. However, all of the trials included patients with moderate renal insufficiency $(\mathrm{CrCl} 30-50 \mathrm{~mL} / \mathrm{min})$. In the pooled analysis of the RE-COVER trials, none of the 117 dabigatran-treated patients with a calculated $\mathrm{CrCl} 30-50 \mathrm{~mL} / \mathrm{min}$ experienced the primary efficacy outcome compared with 5 of the 128 (3.9\%) warfarin-treated patients [15]. In the dabigatran secondary prevention trials (RE-MEDY and RESONATE), the incidence of the primary efficacy endpoint was similar to that of warfarin and placebo, respectively, but the incidence of bleeding outcomes was not reported [29]. The EINSTEIN-DVT trial reported 4 of 121 (3.3\%) rivaroxaban-treated patients with $\mathrm{CrCl}<50 \mathrm{~mL} / \mathrm{min}$ with the primary efficacy endpoint of recurrent symptomatic VTE, while 13 of $120(10.8 \%)$ of the patients experienced the primary safety endpoint of major or CRNM bleeding [16]. There was no difference between patients treated with standard of care. In the EINSTEIN-PE trial, 7 of 211 (3.3\%) and 26 of $209(12.4 \%)$ rivaroxaban-treated patients with calculated $\mathrm{CrCl}<50 \mathrm{~mL} / \mathrm{min}$ experienced the primary efficacy endpoint of recurrent symptomatic VTE or the primary safety endpoint of major or CRNM bleeding, respectively [17]. There was no difference compared with standard of care. In the pooled analysis of the EINSTEIN trials, compared with standard of care, patients with moderate renal insufficiency receiving rivaroxaban had similar efficacy and significantly lower rates of major bleeding ( 0.9 vs $4.1 \%)$ [29]. The AMPLIFY trial reported that 7 of 169 (4.1\%) apixaban-treated patients with $\mathrm{CrCl}<50 \mathrm{~mL} / \mathrm{min}$ developed recurrent VTE or experienced a VTE-related death. The AMPLIFY trial also reported that 5 of 175 (2.9\%) apixabantreated patients with $\mathrm{CrCl}<50 \mathrm{~mL} / \mathrm{min}$ developed the composite of major or CRNM bleeding [18]. Among patients with a CrCL of $30-50 \mathrm{~mL} / \mathrm{min}$ who received edoxaban in the Hokusai-VTE trial, many of whom would have received the reduced dose of $30 \mathrm{mg}$ once daily, rates of the primary efficacy and safety endpoints were numerically lower compared with standard of care (3.0 vs $5.9 \%$ and 10.4 vs $14.3 \%$, respectively) [19]. In a recent meta-analysis, rivaroxaban, apixaban, and dabigatran were associated with lower major or CRNM bleeding in patients with mild renal insufficiency, and were comparable to conventional agents in patients with moderate renal insufficiency [36].

The overall percentage of patients with moderate renal insufficiency is only about $6-8 \%$ in these trials (Table 5).
While clinicians may disregard these data due to the small percentage of patients, these data represent outcomes from several hundred patients with moderate renal insufficiency. For example, patients with moderate renal insufficiency made up 649 patients in the pooled analysis of the EINSTEIN trials and 541 patients in the Hokusai-VTE trial [19, 29]. Few trials evaluating the use of anticoagulants in patients with renal insufficiency have this number of patients. Therefore, these data should provide some confidence on the efficacy and safety of the use of the new oral anticoagulants in patients with moderate renal insufficiency.

In the NOAC trials, there was a wide variation in thrombus burden. In EINSTEIN-DVT, 1,200 of 1,731 $(69 \%)$ rivaroxaban-treated patients had extensive (involving iliac or common femoral veins) DVT [16]. In AMPLIFY, 753 of 1,749 (43\%) apixaban-treated patients had extensive DVT [18]. In Hokusai-VTE, 1,035 of 2,468 (42\%) edoxaban-treated patients had extensive DVT [19]. The extensiveness of clot burden did not have a significant impact on outcomes in the EINSTEIN and AMPLIFY trials, while these data have not been reported in the HokusaiVTE trial. The RE-COVER I and II trials did not report the anatomical extent of the DVT.

In RE-COVER I and RE-COVER II, 270 (21.2\%) and 298 (23.3 \%) of the dabigatran-treated patients had PE only [14, 15]. In EINSTEIN-PE, 597 (24.7\%) rivaroxabantreated patients had extensive (multiple lobes and $>25 \%$ of the entire vasculature) thrombosis [17]. In AMPLIFY, $357(38.4 \%)$ of the apixaban-treated patients with pulmonary embolism had extensive $(\geq 2$ lobes involving $\geq 50 \%$ of the vasculature for each lobe) thrombosis [18]. In Hokusai-VTE, 743 (45\%) edoxaban-treated patients had extensive (multiple lobes and $\geq 25 \%$ of the vasculature) PE [19]. Hokusai-VTE was the only trial to report high-mortality risk features (right ventricular dysfunction, elevations in cardiac biomarkers, or severity indices). There were 454 patients $(27.5 \%)$ with elevations in $\mathrm{N}$-terminal pro-brain natriuretic peptide (NT-proBNP) and 172 patients $(34.5 \%)$ with right ventricular dysfunction identified on CT scan. Venous thromboembolism recurrence was reduced in edoxaban-treated patients with $\mathrm{PE}$ and elevated NT-proBNP or with right ventricular dysfunction compared with patients who received standard of care [19].

\section{Discussion}

Four oral anticoagulants have migrated through drug development and completed phase III trials in acute VTE treatment. These trials had strikingly similar inclusion and exclusion criteria (Tables 1, 2). The primary efficacy 
endpoints, the incidence of recurrent VTE, and the objective evaluations to determine those endpoints were nearly identical (Tables 1, 4, 5). The major bleeding safety endpoint was determined by standardized definitions that were also nearly identical. Not surprisingly, there was not a wide variation (2.1-3.2\%) in the incidence of the primary efficacy endpoint nor a wide range $(0.5-1.2 \%)$ in the incidence of symptomatic PE across trials. Similarly, major bleeding was quite comparable with the new agents, ranging from 0.6 to $1.6 \%$ across the trials. Because of different CRNM bleeding definitions, there was a wide variation in event rates, ranging from a low incidence in RE-COVER II (3.8\%) to a much higher incidence in EINSTEIN-PE $(9.5 \%)$. Finally, while this information was not in the trials and prescription benefit coverage may vary, we found the current average wholesale price for the acute VTE treatment dosing to be: (i) dabigatran US $\$ 11.67$ per day, (ii) rivaroxaban US\$11.45 per day, and (iii) apixaban $\$ 11.67$ per day, further signaling the similarities between the agents [37].

Major and CRNM bleeding was significantly reduced in those receiving dabigatran, apixaban, and edoxaban in their respective trials, but not with rivaroxaban when compared with standard of care. The incidence of CRNM bleeding was, however, similar in the RE-COVER I (4.0 \%), RECOVER II $(3.8 \%)$, and AMPLIFY (3.8\%) trials. The incidences of CRNM bleeding between EINSTEIN-DVT $(7.3 \%)$, EINSTEIN-PE $(9.5 \%)$, and Hokusai-VTE $(7.2 \%)$ were similar as well $[18,19,29]$.

In the EINSTEIN-DVT trial, there were actually more suspected VTE events in the rivaroxaban group compared with the standard-of-care group (13.3 vs $12.5 \%$ ), which suggest against a diagnostic-suspicion bias [16]. Of these suspected events, all of which were confirmed by the adjudication committee, $15.7 \%$ were in the rivaroxaban group and $23.7 \%$ occurred in the standard-of-care group. The same was found in the EINSTEIN-PE trial, where there were more suspected VTE events in the rivaroxaban group (20.3 vs $18.8 \%$ ) [17]. Of these suspected events, $10.2 \%$ were confirmed by the adjudication committee in the rivaroxaban group compared with $9.7 \%$ in the standard-of-care group. Therefore, it does not seem that the open-label design of the EINSTEIN trials produced a diagnostic-suspicion bias that favored rivaroxaban.

Early trials have shown that symptomatic, recurrent VTE is common in the first month of treatment, especially if anticoagulation is subtherapeutic [38, 39]. To overcome the slow onset of warfarin, standard practice has evolved to overlap adjusted-dose UFH or LMWH with warfarin for a minimum of 5-10 days to prevent thrombus extension or recurrence. The optimal intensity and duration of this initial anticoagulation period has been elusive $[40,41]$. Both AMPLIFY and EINSTEIN trials compensated for this uncertainty by employing an escalated dose for 7 and 21 days, respectively. These regimens may help identify that optimum time period.

Approximately $70-90 \%$ of patients receiving rivaroxaban or apixaban received an injectable anticoagulant for up to 2 days (Table 4). While this may lead some clinicians to conclude that a short course of an injectable anticoagulant is still needed with these agents, only a minority in the EINSTEIN-DVT (4\%), EINSTEIN-PE (35\%), and AMPLIFY (31\%) trials received more than 24 hours of parenteral anticoagulation treatment [16-18]. This finding may actually reflect the delay in evaluating and enrolling a patient in a clinical trial, as patients are typically initiated on treatment as part of routine care before identification as a potential study subject. Efficacy and safety outcomes in these trials were not different based on patients receiving an injectable anticoagulant or the duration of use. In the Hokusai-VTE trial, no differences in the primary efficacy and safety outcomes were observed when results were stratified by median duration of parenteral anticoagulation [19]. These data are not available from the RE-COVER trials. In the EINSTEIN-DVT trial, the primary efficacy outcome was similar for patients not receiving an injectable anticoagulant before randomization ( $1.9 \%$ rivaroxaban vs $2.0 \%$ standard of care) to those receiving an injectable (2.1\% rivaroxaban vs $3.4 \%$ standard of care) [16]. Similar results were demonstrated for those in the AMPLIFY trial not receiving an injectable (1.7\% apixaban vs $3.2 \%$ standard of care) and those receiving an injectable (2.4\% apixaban vs $2.6 \%$ standard of care) [18]. Because over $90 \%$ of patients in EINSTEIN$P E$ received an injectable, the results have been presented as those receiving 1 day of an injectable $(1.9 \%$ rivaroxaban vs $1.6 \%$ standard of care) or more than 1 day (1.9\% for both groups) [17]. Therefore, requiring 1-2 days of an injectable anticoagulant with rivaroxaban or apixaban does not seem justified. However, if patients are initially treated with an injectable anticoagulant, switching them to rivaroxaban or apixaban can be performed based on the experience from these trials.

Dabigatran, apixaban, and rivaroxaban safety and efficacy has been established for long-term secondary VTE prevention compared with placebo. Dabigatran has shown non-inferiority compared with warfarin for long-term secondary prevention of VTE. The NOACs represent therapeutic options for those patients deemed at continuous VTE risk. Furthermore, the option for tailoring therapy among agents exists: (i) compliance, favoring once-daily rivaroxaban; (ii) concern for bleeding, favoring reduceddose apixaban (2.5 mg twice daily); and (iii) warfarin alternative, favoring dabigatran. While data on NOACs in VTE are emerging, recent studies with aspirin have become available as well. Two double-blind randomized trials have 
Table 8 Practical considerations for novel anticoagulant selection

\begin{tabular}{|c|c|c|}
\hline Co-morbidity or characteristic & Agent & Rationale \\
\hline Initial parenteral therapy & $\begin{array}{l}\text { Apixaban, dabigatran, edoxaban } \\
\text { rivaroxaban }\end{array}$ & $\begin{array}{l}\text { Allowance of } 48-72 \mathrm{~h} \text { initial treatment before } \\
\text { randomization }\end{array}$ \\
\hline Renal dysfunction $\mathrm{CrCl} \geq 25 \mathrm{~mL} / \mathrm{min}$ to $\leq 30 \mathrm{~mL} / \mathrm{min}$ & Apixaban & Trial exclusion criteria \\
\hline Low body weight, $<60 \mathrm{~kg}$ & Edoxaban & Trial dosing adjustment \\
\hline Cancers and thrombophilia & None & Limited trial data \\
\hline Affordability & None, aspirin, or patient preference & Similar costs \\
\hline Concurrent clopidogrel therapy & Rivaroxaban & Concomitant use allowed in trial \\
\hline Chronic NSAID use & Apixaban & Concomitant use allowed in trial \\
\hline PE with elevated biomarkers & Edoxaban & Trial sub-populations with high-risk features \\
\hline Compliance challenges & Rivaroxaban, edoxaban & Once daily dosing \\
\hline Prior MI & Apixaban, edoxaban, rivaroxaban & MI events associated with dabigatran \\
\hline Propensity for bleeding & Apixaban, rivaroxaban & Clinical reductions in major bleeding \\
\hline $\begin{array}{l}\text { Multiple concomitant medications with potential drug } \\
\text { interactions }\end{array}$ & Edoxaban, apixaban & $\begin{array}{l}\text { Edoxaban and apixaban allow for a dose } \\
\text { reduction }\end{array}$ \\
\hline
\end{tabular}

$\mathrm{CrCl}$ estimated creatinine clearance, $M I$ myocardial infarction, $N S A I D$ non-steroidal anti-inflammatory drug, $P E$ pulmonary embolism

shown efficacy and safety in patients with a first episode of unprovoked VTE. Patients who received low-dose aspirin (100 mg daily) after completing an initial course of anticoagulation had a reduction in VTE recurrence without an increase in major bleeding episodes when compared with placebo [42, 43]. It should be noted that the relative reduction in recurrent VTE with aspirin in these trials is between 25 and $40 \%$ over $2-4$ years, and the reduction in the NOAC trials is approximately $80-90 \%$ in 1 year $[16$, $28,30,42,43]$. Therefore, aspirin may be a logical alternative for patients who cannot tolerate NOACs or warfarin, or have a high bleeding risk.

\section{Conclusions}

Clinicians now have three VTE treatment options to consider: conventional parenteral therapy with UFH, LMWH, or fondaparinux as a bridge to warfarin, monotherapy with an NOAC, or conventional parenteral therapy as a bridge to an NOAC. Use of NOACs can maintain efficacy compared with standard of care, while significantly reducing either major bleeding or major and CRNM bleeding. This safety benefit, along with the simplification of therapy compared with warfarin, make treatment of VTE with a NOAC an attractive option. While cost of the NOACs may be an issue, the potential ability to reduce hospitalizations and reduce length of stay could offset medication costs for third-party payers. The role of these new oral agents in the setting of cancer and VTE and their role in the treatment of massive DVT and high-risk PE where thrombolysis or mechanical intervention is required needs to be established.
Rivaroxaban and apixaban offer the advantage of no need for injectable therapy and a pure oral therapy approach to the treatment of VTE. A dose adjustment is needed at day 7 or 21 with the use of apixaban and rivaroxaban, respectively, which will require important communication between healthcare providers and patients during transition of care. Dabigatran and edoxaban do not require any dose alterations in the first weeks of therapy and may provide a simpler approach after patient discharge, but the need for a minimum of 5 days of injectable therapy may not be desirable.

NOACs have not been directly compared in clinical trials for VTE treatment. Despite pitfalls with cross-trial comparisons, inevitably clinicians will be forced to make treatment decisions [44]. While there were differences in NOAC study design and dosing regimens, enrollment criteria, population, and endpoint measures, ultimately outcomes were comparable. With efficacy, safety, and cost similar, tailoring selection based on patient co-morbidities, patient and clinician preference, dosing convenience, and adverse events becomes magnified. Practical considerations (Table 8) and patient preference may be deciding factors in drug selection and successful treatment.

Acknowledgements Editorial support was provided by Meryl Gersh, PhD, and Emma Platt, PhD, of AlphaBioCom, LLC, King of Prussia, PA, USA. AlphaBioCom has received funding from Daiichi Sankyo Inc., Parsipanny, NJ, USA.

Funding source No funding was requested or received for the preparation of this manuscript by the authors.

Conflict of interest Dr. Dobesh has served as a consultant for Pfizer/BMS, Janssen Pharmaceuticals, and Daiichi Sankyo. He has also received research funding from Daiichi Sankyo. Dr. Fanikos 
served as a consultant for Boehringer Ingelheim and Marathon Pharma.

Open Access This article is distributed under the terms of the Creative Commons Attribution Noncommercial License which permits any noncommercial use, distribution, and reproduction in any medium, provided the original author(s) and the source are credited.

\section{References}

1. White RH. The epidemiology of venous thromboembolism. Circulation. 2003;107:I4-8. doi:10.1161/01.CIR.0000078468. 11849.66 .

2. Stein PD, Matta F, Dalen JE. Is the campaign to prevent VTE in hospitalized patients working? Chest. 2011;139:1317-21. doi:10. 1378/chest.10-1622.

3. Spencer FA, Emery C, Lessard D, Anderson F, Emani S, Aragam $\mathrm{J}$, et al. The Worcester Venous Thromboembolism study: a population-based study of the clinical epidemiology of venous thromboembolism. J Gen Intern Med. 2006;21:722-7. doi:10. 1111/j.1525-1497.2006.00458.x.

4. Zhu T, Martinez I, Emmerich J. Venous thromboembolism: risk factors for recurrence. Arterioscler Thromb Vasc Biol. 2009;29:298-310. doi:10.1161/ATVBAHA.108.182428.

5. Galioto NJ, Danley DL, Van Maanen RJ. Recurrent venous thromboembolism. Am Fam Physician. 2011;83:293-300.

6. Prandoni P, Noventa F, Ghirarduzzi A, Pengo V, Bernardi E, Pesavento $\mathrm{R}$, et al. The risk of recurrent venous thromboembolism after discontinuing anticoagulation in patients with acute proximal deep vein thrombosis or pulmonary embolism. A prospective cohort study in 1,626 patients. Haematologica. 2007;92:199-205.

7. Iorio A, Kearon C, Filippucci E, Marcucci M, Macura A, Pengo $\mathrm{V}$, et al. Risk of recurrence after a first episode of symptomatic venous thromboembolism provoked by a transient risk factor: a systematic review. Arch Intern Med. 2010;170:1710-6. doi:10. 1001/archinternmed.2010.367.

8. Kearon C, Akl EA, Comerota AJ, Prandoni P, Bounameaux H, Goldhaber SZ, et al. Antithrombotic therapy for VTE disease: Antithrombotic Therapy and Prevention of Thrombosis, 9th ed: American College of Chest Physicians Evidence-Based Clinical Practice Guidelines. Chest. 2012;141:e419S-94S. doi:10.1378/ chest.11-2301.

9. Heit JA, Silverstein MD, Mohr DN, Petterson TM, O'Fallon WM, Melton LJ 3rd. Predictors of survival after deep vein thrombosis and pulmonary embolism: a population-based, cohort study. Arch Intern Med. 1999;159:445-53.

10. Kucher N, Rossi E, De Rosa M, Goldhaber SZ. Massive pulmonary embolism. Circulation. 2006;113:577-82. doi:10.1161/ CIRCULATIONAHA.105.592592.

11. Tagalakis V, Patenaude V, Kahn SR, Suissa S. Incidence of and mortality from venous thromboembolism in a real-world population: the Q-VTE Study Cohort. Am J Med. 2013;126(832):e13-21. doi:10.1016/j.amjmed.2013.02.024.

12. Spyropoulos AC, Lin J. Direct medical costs of venous thromboembolism and subsequent hospital readmission rates: an administrative claims analysis from 30 managed care organizations. J Manag Care Pharm. 2007;13:475-86.

13. Fanikos J, Rao A, Seger AC, Carter D, Piazza G, Goldhaber SZ. Hospital costs of acute pulmonary embolism. Am J Med. 2013;126:127-32. doi:10.1016/j.amjmed.2012.07.025.

14. Schulman S, Kearon C, Kakkar AK, Mismetti P, Schellong S, Eriksson $\mathrm{H}$, et al. Dabigatran versus warfarin in the treatment of acute venous thromboembolism. N Engl J Med. 2009;361:2342-52. doi:10.1056/NEJMoa0906598.

15. Schulman S, Kakkar AK, Goldhaber SZ, Schellong S, Eriksson $\mathrm{H}$, Mismetti P, et al. Treatment of acute venous thromboembolism with dabigatran or warfarin and pooled analysis. Circulation. 2014;129:764-72. doi:10.1161/CIRCULATIONAHA.113. 004450.

16. Bauersachs R, Berkowitz SD, Brenner B, Buller HR, Decousus $\mathrm{H}$, The EINSTEIN Investigators, et al. Oral rivaroxaban for symptomatic venous thromboembolism. N Engl J Med. 2010;363:2499-510. doi:10.1056/NEJMoa1007903.

17. Buller HR, Prins MH, Lensin AW, Decousus H, Jacobson BF, The EINSTEIN-PE Investigators, et al. Oral rivaroxaban for the treatment of symptomatic pulmonary embolism. N Engl J Med. 2012;366:1287-97. doi:10.1056/NEJMoa1113572.

18. Agnelli G, Buller HR, Cohen A, Curto M, Gallus AS, Johnson M, et al. Oral apixaban for the treatment of acute venous thromboembolism. N Engl J Med. 2013;369:799-808. doi:10.1056/ NEJMoa1302507.

19. Buller HR, Decousus H, Grosso MA, Mercuri M, Middeldorp S, The Hokusai-VTE Investigators, et al. Edoxaban versus warfarin for the treatment of symptomatic venous thromboembolism. N Engl J Med. 2013;369:1406-15. doi:10.1056/ NEJMoa1306638.

20. Fiessinger JN, Huisman MV, Davidson BL, Bounameaux H, Francis CW, Eriksson H, et al. Ximelagatran vs low-molecularweight heparin and warfarin for the treatment of deep vein thrombosis: a randomized trial. JAMA. 2005;293:681-9. doi:10. 1001/jama.293.6.681.

21. Raskob G, Buller H, Prins M, Segers A, Shi M, Schwocho L, et al. Edoxaban for the long-term treatment of venous thromboembolism: rationale and design of the Hokusai-VTE study. J Thromb Haemost. 2013;. doi:10.1111/jth.12230.

22. Tan M, van Rooden CJ, Westerbeek RE, Huisman MV. Diagnostic management of clinically suspected acute deep vein thrombosis. Br J Haematol. 2009;146:347-60. doi:10.1111/j. 1365-2141.2009.07732.x.

23. Nijkeuter M, Hovens MM, Davidson BL, Huisman MV. Resolution of thromboemboli in patients with acute pulmonary embolism: a systematic review. Chest. 2006;129:192-7. doi:10. 1378/chest.129.1.192.

24. Fox JC, Bertoglio KC. Emergency physician performed ultrasound for DVT Evaluation. Thrombosis. 2011;2011:938709. doi:10.1155/2011/938709.

25. Prandoni $\mathrm{P}$, Lensing AW, Bernardi E, Villalta S, Bagatella $\mathrm{P}$, Girolami A, et al. The diagnostic value of compression ultrasonography in patients with suspected recurrent deep vein thrombosis. Thromb Haemost. 2002;88:402-6. doi:10.1267/ THRO88030402.

26. Schulman S, Kearon C. Subcommittee on Control of Anticoagulation of the Scientific and Standardization Committee of the International Society on Thrombosis and Haemostasis. Definition of major bleeding in clinical investigations of antihemostatic medicinal products in non-surgical patients. $\mathbf{J}$ Thromb Haemost. 2005;3:692-4. doi:10.1111/j.1538-7836.2005.01204.x.

27. van Gogh I, Buller HR, Cohen AT, Davidson B, Decousus H, Gallus AS, et al. Idraparinux versus standard therapy for venous thromboembolic disease. N Engl J Med. 2007;357:1094-104. doi:10.1056/NEJMoa064247.

28. Agnelli G, Buller HR, Cohen A, Curto M, Gallus AS, Johnson M, et al. Apixaban for extended treatment of venous thromboembolism. N Engl J Med. 2013;368:699-708. doi:10.1056/ NEJMoa1207541.

29. Prins MH, Lensing AW, Bauersachs R, van Bellen B, Bounameaux $\mathrm{H}$, Brighton TA, et al. Oral rivaroxaban versus standard therapy for the treatment of symptomatic venous 
thromboembolism: a pooled analysis of the EINSTEIN-DVT and PE randomized studies. Thromb J. 2013;11:21. doi:10.1186/ 1477-9560-11-21.

30. Schulman S, Kearon C, Kakkar AK, Schellong S, Eriksson H, Baanstra D, et al. Extended use of dabigatran, warfarin, or placebo in venous thromboembolism. $\mathrm{N}$ Engl $\mathrm{J}$ Med. 2013;368:709-18. doi:10.1056/NEJMoa1113697.

31. Lyman GH, Khorana AA, Kuderer NM, Lee AY, Arcelus JI, Balaban EP, et al. Venous thromboembolism prophylaxis and treatment in patients with cancer: American Society of Clinical Oncology clinical practice guideline update. J Clin Oncol. 2013;31:2189-204. doi:10.1200/JCO.2013.49.1118.

32. Nicolaides A, Hull RD, Fareed J. Diagnosis and anticoagulant treatment. Clin Appl Thromb Hemost. 2013;19:187-98. doi:10. 1177/1076029612474840n.

33. Lee AY, Levine MN, Baker RI, Bowden C, Kakkar AK, Prins M, et al. Low-molecular-weight heparin versus a coumarin for the prevention of recurrent venous thromboembolism in patients with cancer. N Engl J Med. 2003;349:146-53. doi:10.1056/ NEJMoa025313.

34. Sardar P, Chatterjee S, Herzog E, Pekler G, Mushiyev S, Pastori $\mathrm{LJ}$, et al. New oral anticoagulants in patients with cancer: current state of evidence. Am J Ther. 2014;. doi:10.1097/MJT. 0000000000000055 .

35. The National Comprehensive Cancer Network. NCCN Clinical Practice Guidelines: Venous Thrombemobolism Disease, Version 2. Available at http://www.nccn.org/professionals/physician_gls/ f_guidelines.asp\#vte. Accessed on Sep 112014.

36. Sardar P, Chatterjee S, Herzog E, Nairooz R, Mukherjee D, Halperin JL. Novel oral anticoagulants in patients with renal insufficiency: a meta-analysis of randomized trials. Can J Cardiol. 2014;30:888-97. doi:10.1016/j.cjca.2014.04.015.
37. McKesson Connect. Industry benchmark pricing. Available at https://connect.mckesson.com/portal/site/smo/Home/?link=tn. Accessed Sep 112014.

38. Hull RD, Raskob GE, Hirsh J, Jay RM, Leclerc JR, Geerts WH, et al. Continuous intravenous heparin compared with intermittent subcutaneous heparin in the initial treatment of proximal-vein thrombosis. N Engl J Med. 1986;315:1109-14. doi:10.1056/ NEJM198610303151801.

39. Brandjes DP, Heijboer H, Buller HR, de Rijk M, Jagt H, ten Cate JW. Acenocoumarol and heparin compared with acenocoumarol alone in the initial treatment of proximal-vein thrombosis. N Engl J Med. 1992;327:1485-9. doi:10.1056/NEJM199211193272103.

40. Hull R, Delmore T, Genton E, Hirsh J, Gent M, Sackett D, et al. Warfarin sodium versus low-dose heparin in the long-term treatment of venous thrombosis. N Engl J Med. 1979;301:855-8. doi:10.1056/NEJM197910183011602.

41. Hull RD, Raskob GE, Rosenbloom D, Panju AA, Brill-Edwards $\mathrm{P}$, Ginsberg JS, et al. Heparin for 5 days as compared with 10 days in the initial treatment of proximal venous thrombosis. N Engl J Med. 1990;322:1260-4. doi:10.1056/ NEJM199005033221802.

42. Becattini C, Agnelli G, Schenone A, Eichinger S, Bucherini E, Silingardi M, et al. Aspirin for preventing the recurrence of venous thromboembolism. N Engl J Med. 2012;366:1959-67. doi:10.1056/NEJMoa1114238.

43. Brighton TA, Eikelboom JW, Mann K, Mister R, Gallus A, Ockelford $\mathrm{P}$, et al. Low-dose aspirin for preventing recurrent venous thromboembolism. N Engl J Med. 2012;367:1979-87. doi:10. 1056/NEJMoa1210384.

44. Cannon CP, Kohli P. Danger ahead: watch out for indirect comparisons! J Am Coll Cardiol. 2012;60:747-8. doi:10.1016/j. jacc.2012.05.012. 